\title{
Heeding Daedalus: Optimal Inflation and the Zero Lower Bound
}

\begin{abstract}
This paper reexamines the implications for monetary policy of the zero lower bound on nominal interest rates in light of recent experience. The ZLB contributed little to the sharp output declines in many economies in 2008, but it is a significant factor slowing recovery. Model simulations imply that an additional 4 percentage points of rate cuts would have limited the rise in the U.S. unemployment rate and would bring unemployment and inflation more quickly to steady-state values, but the ZLB precludes these actions, at a cost of $\$ 1.8$ trillion in forgone U.S. output over four years. If recent events presage a shift to a significantly more adverse macroeconomic climate, then 2 percent steady-state inflation may provide an inadequate buffer against the ZLB, assuming a standard Taylor rule. Stronger countercyclical fiscal policy or alternative monetary policy strategies could mitigate the ZLB's effects, but even with such policies an inflation target of 1 percent or lower could entail significant costs.
\end{abstract}

Icarus, my son, I charge you to keep at a moderate height, for if you fly too low the damp will clog your wings, and if too high the heat will melt them.

-Bulfinch's Mythology, Chapter XX

apan's sustained deflation and near-zero short-term interest rates beginning in the 1990s prompted an outpouring of research on the implications of the zero lower bound (ZLB) on nominal interest rates for monetary policy and the macroeconomy. In the presence of nominal rigidities, the ZLB will at times constrain the central bank's ability to reduce nominal, and thus real, interest rates in response to negative shocks to the economy. This inability to reduce real rates as low as desired impairs the ability of monetary policy to stabilize output and inflation. The quantitative importance of the ZLB depends on how often and how tightly the constraint binds, a key determinant of which is the steady-state inflation rate targeted by the central bank. 
If that rate is sufficiently high, the ZLB will rarely impinge on monetary policy and the macroeconomy. If sufficiently low, the ZLB may have more deleterious effects. All else equal, then, the presence of the ZLB argues for a higher steady-state inflation rate.

Of course, not all else is equal. Since Martin Bailey (1956), economists have identified and studied other sources of distortions related to inflation besides the ZLB. Several of these-including transactions costs, real distortions associated with nonzero rates of inflation, and nonneutralities in the tax system-argue for targeting steady-state inflation rates of zero or below. Others-including asymmetries in wage setting, imperfections in labor markets, distortions related to imperfect competition, and measurement bias-argue for positive steady-state inflation (see, for example, Akerlof, Dickens, and Perry 1996). Balancing these opposing influences, central banks around the globe have sought to heed the mythical Greek inventor Daedalus's advice to his son by choosing an inflation goal neither too low nor too high. In practice, many central banks have articulated annual inflation goals centered on 2 to 3 percent (Kuttner 2004). Simulations of macroeconomic models where monetary policy follows a version of the Taylor (1993) rule indicate that with an inflation target of 2 percent, the ZLB will act as a binding constraint on monetary policy relatively frequently (Reifschneider and Williams 2000; Billi and Kahn 2008). But these simulations also predict relatively modest effects of the ZLB on macroeconomic volatility with a 2 percent target, because the magnitude of the constraint will be relatively small and its duration relatively brief. Only with inflation targets of 1 percent or lower does the ZLB engender significantly higher variability of output and inflation in these simulations. In summary, these studies find a 2 percent inflation target to be an adequate buffer against adverse effects arising from the ZLB.

The economic tumult of the past two years, with short-term interest rates near zero in most major industrial economies, has challenged this conclusion. As figure 1 shows, the global financial crisis and ensuing recession have driven many major central banks to cut their short-term policy rates effectively to zero; other central banks constrained by the ZLB include the Swedish Riksbank and the Swiss National Bank. Despite these aggressive monetary policy actions, and despite considerable stimulus from fiscal policy, these economies are suffering their worst downturns in many decades (figure 2). In addition, fears of deflation have intensified as falling commodity prices and growing economic slack put downward pressure on prices generally. As figure 3 shows, overall consumer price index (CPI) inflation 
Figure 1. Central Bank Policy Rates in Major Industrial Countries, 2003-09 and Forecast 2009-10

Percent per year

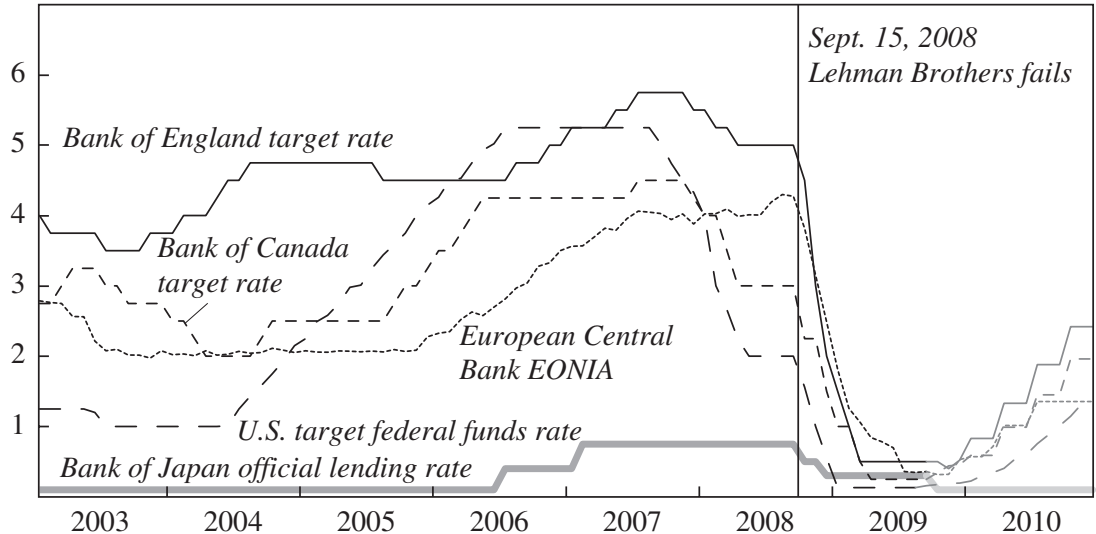

Sources: Board of Governors of the Federal Reserve System, table H.15, "Selected Interest Rates," various issues; Bloomberg data; foreign central bank data.

a. Faded lines are projections based on interest rate futures prices as of September 18, 2009. EONIA, euro overnight index average.

Figure 2. Real GDP in Major Industrial Countries, 2007-09 and Forecast 2009-11

Index, 2007Q4 = 100

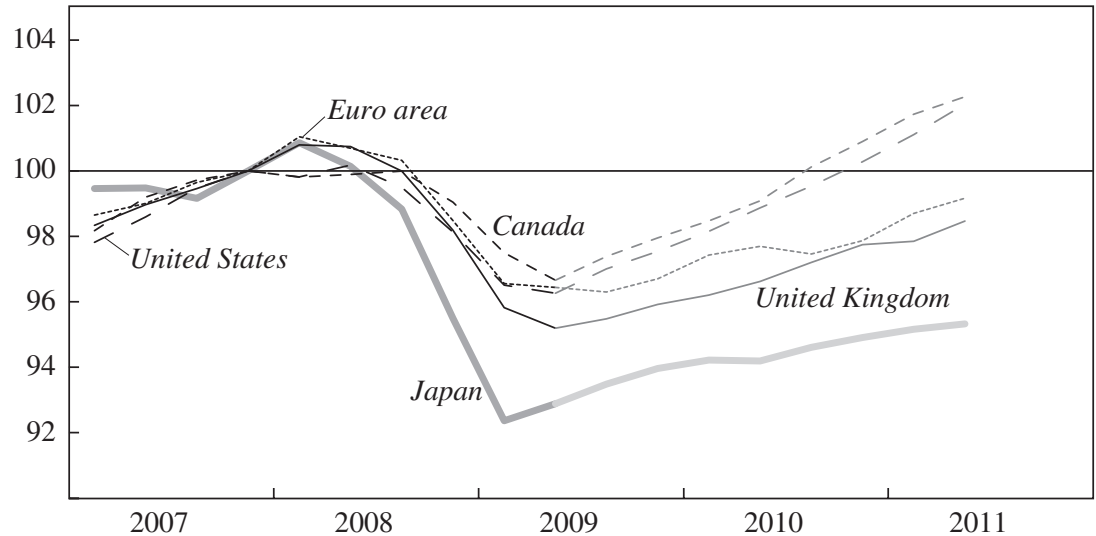

Sources: Bureau of Economic Analysis data; Consensus Economics, "Consensus Forecasts," September 2009; European Central Bank data; Haver Analytics; authorís calculations.

a. Faded lines are projections based on the September 2009 "Consensus Forecasts." 
Figure 3. Inflation in Major Industrial Countries, 2003-09 and Forecast 2010-11

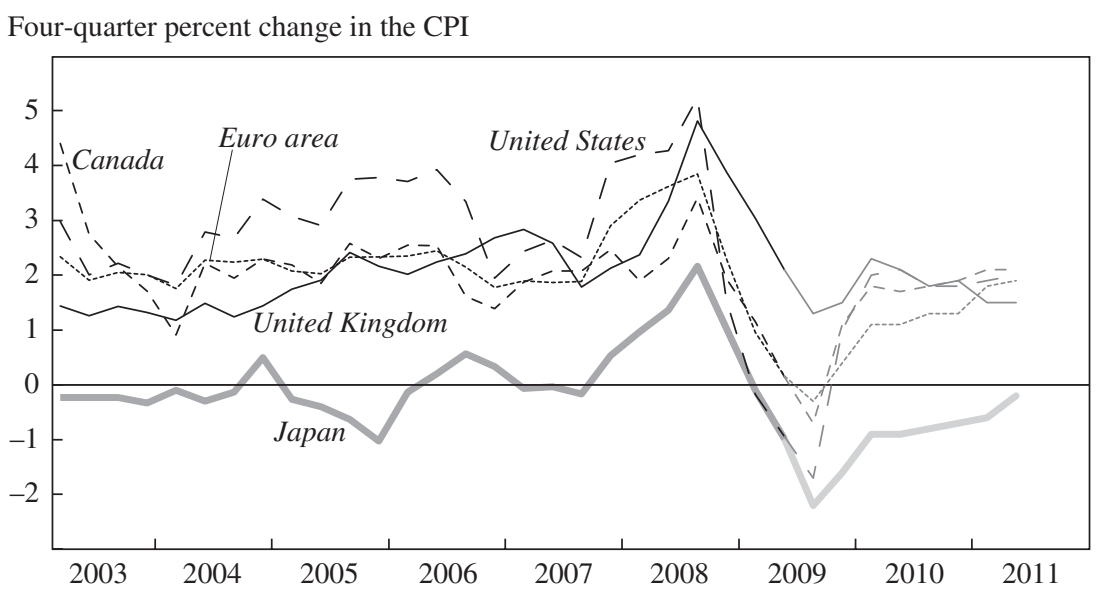

Sources: Bureau of Economic Analysis data; Consensus Economics, "Consensus Forecasts," September 2009; European Central Bank data; Haver Analytics; author's calculations.

a. Faded lines are projections based on the September 2009 "Consensus Forecasts."

has fallen sharply in all major industrial economies. Much of this decline is due to falling commodity prices, especially energy prices, but core measures of CPI inflation have come down in these economies over the past year as well.

Given these conditions, a strong case can be made for the desirability of additional monetary stimulus in the United States and in many other countries. But with rates already effectively at zero, this is not an option, at least in terms of conventional monetary actions. Several central banks have therefore taken unconventional measures, such as changes in the composition and size of the asset side of their balance sheets. But the short- and long-term effects of these unconventional policies remain highly uncertain, and in any case such policies are at best imperfect substitutes for standard interest rate cuts.

This paper examines the effects of the ZLB on the current recession and reevaluates the expected future effects associated with the ZLB and the optimal inflation rate in light of new information and research. ${ }^{1}$ There are

1. I do not examine the issues related to multiple equilibria studied by Benhabib, SchmittGrohé, and Uribe (2001). Instead, like Evans, Guse, and Honkapohja (2008), I assume that discretionary fiscal policy will intervene to ensure that a unique steady state exists toward which the economy tends to revert. 
two main findings. First, the ZLB did not materially contribute to the sharp declines in output in the United States and many other economies through the end of 2008, but it is a significant factor slowing their recovery. Model simulations for the United States imply that an additional 4 percentage points of interest rate cuts would have kept the unemployment rate from rising as much as it has and would bring the unemployment and inflation rates more quickly to their steady-state values, but the ZLB precludes these actions. This inability to lower interest rates comes at a cost of about $\$ 1.8$ trillion of forgone output over four years. Second, if recent events are a harbinger of a significantly more adverse macroeconomic climate than experienced over the past two decades, then a 2 percent steady-state inflation rate may provide an inadequate buffer against the ZLB having noticeable deleterious effects on the macroeconomy, assuming the central bank follows the standard Taylor rule. In such an adverse environment, stronger systematic countercyclical fiscal policy, or alternative monetary policy strategies, or both may be needed to mitigate the harmful effects of the ZLB with a 2 percent inflation target. Even with such policies, an inflation target of 1 percent or lower could entail significant costs in terms of macroeconomic volatility.

The paper is organized as follows. Section I examines the effects of the ZLB on the U.S. economy during the current episode. Section II reexamines the assumptions and results of past calculations of the macroeconomic effects of the ZLB under the Taylor rule. Section III evaluates alternative monetary and fiscal policies designed to mitigate the effects of the ZLB. Section IV concludes.

\section{Lessons from the Current Recession}

The ongoing global recession provides compelling proof that the ZLB can be a significant constraint on monetary policy, with potentially enormous macroeconomic repercussions. This section investigates two questions regarding the role of the ZLB in the current episode. First, how should one interpret the widespread phenomenon of central banks lowering their policy interest rates to near zero? Second, what are the consequences of the ZLB in terms of the depth of the recession and the speed of recovery?

The fact that central banks have found themselves constrained by the ZLB should not be surprising; in fact, one of the three main "lessons" offered by David Reifschneider and Williams (2000) was that central banks pursuing an inflation goal of around 2 percent would encounter the ZLB 
relatively frequently. ${ }^{2}$ For example, in a briefing paper prepared for the Federal Open Market Committee (2002) Reifschneider and Williams find that with a 2 percent inflation target, roughly in line with the practices of many major central banks, a calibrated version of the Taylor rule (1993) hits the ZLB about 10 percent of the time in simulations of the Federal Reserve Board's FRB/US macroeconometric model. Given that inflation has been centered around 2 percent in the United States since the mid-1990s, it was fully predictable that the ZLB would at some point become an issueeither as a threat, as in 2004, or as a reality, as it is today.

Indeed, the fact that many central banks have already run up against the ZLB is evidence that they have learned a second lesson from recent research, namely, that policymakers should not shy away from the ZLB, but should instead "embrace" it. A common theme in that research is that when the economy weakens significantly or deflation risks arise, the central bank should act quickly and aggressively to get interest rates down, to maximize the monetary stimulus in the system when the economy is weakening. "Keeping your powder dry" is precisely the worst thing to do. Figure 4 shows nominal and ex post real rates on short-term Treasury securities going back to the 1920s. Despite a low rate of inflation and three recessions, nominal interest rates did not once approach the ZLB in that decade. That the ZLB appears to be a greater problem today than in the 1950s and early 1960s, when inflation was also low, may reflect "better" monetary policy in the more recent period. Indeed, a comparison of estimated Taylor-type rules covering that period and the more recent past indicates that short-term interest rates were far less sensitive to movements in output and inflation during the earlier period (Romer and Romer 2002). Of course, the U.S. economy and financial system were very different 50 years ago, so other factors may also explain the differences in interest rate behavior.

To answer the second question, I conduct counterfactual simulations of the Federal Reserve's FRB/US model in which the Federal Reserve is

2. Note that the lower bound on nominal rates does not necessarily equal zero. On one hand, lowering the rate below some small positive value may generate costly disruptions in money markets and other short-term financing markets. In this case central banks may choose never to lower rates all the way to zero, making the effective lower bound a small positive number. On the other hand, a central bank can in principle lower interest rates below zero by charging interest on reserves. However, there are still limits to how low interest rates can go, because banks and other agents can choose to hold currency instead, which yields zero interest less a holding cost $\kappa$, equal to the cost of safely storing and transporting cash. So, instead of a zero bound, there is a $-\kappa$ lower bound on shortterm rates. 
Figure 4. Interest Rates on Treasury Bills, 1922-2009a

Percent per year (quarterly averages)

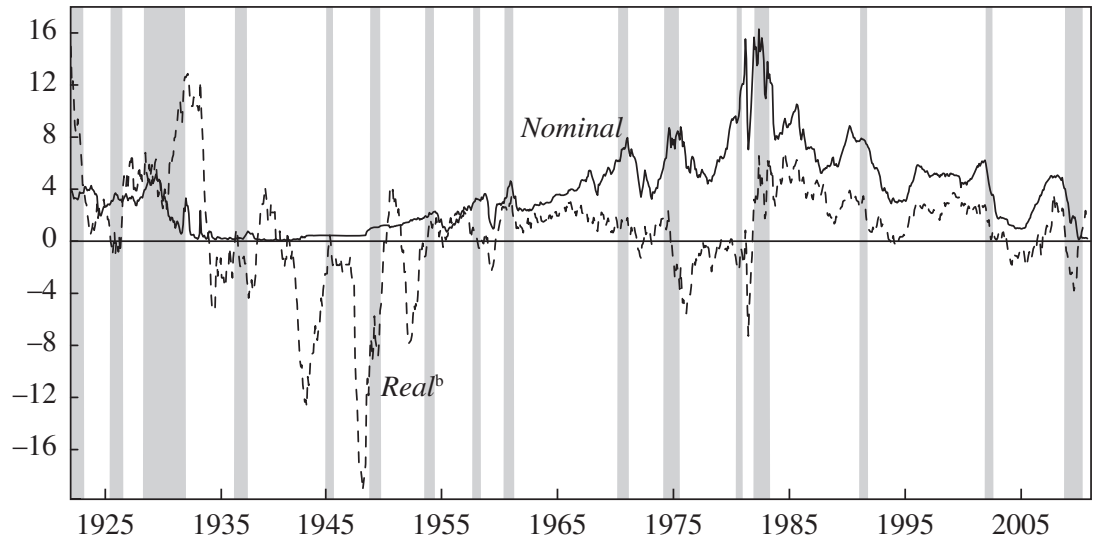

Sources: Board of Governors of the Federal Reserve system, tabel H.15, "Selected Interest Rates," various issues; Bureau of Labor Statistics data; author's calculations.

a. From January 1922 to December 1930, rate on short-term Treasury securities; after December 1930, rate implied by the auction high on three-month Treasury bills. Shaded bands indicate recessions.

b. Nominal rate minus the change in the headline CPI over the preceding 12 months.

not constrained by the ZLB. ${ }^{3}$ These simulations are best thought of as scenarios where the economy enters the current episode with a higher steady-state inflation rate, and therefore the Federal Reserve has a larger interest rate buffer to work with. I consider experiments in which the Federal Reserve is able to lower the federal funds rate by up to 600 basis points more than it has. For comparison, Glenn Rudebusch (2009) finds, based on an estimated monetary policy rule and Federal Open Market Committee (FOMC) forecasts, that in the absence of the ZLB the funds rate would be predicted to fall to about -5 percent. Again, these experiments are not real policy options available to the Federal Reserve. But they allow me to quantify the effects of the ZLB on the recent trajectory of the U.S. economy.

In evaluating the role played by the ZLB, it is important to get the timing of events right. Private forecasters did not anticipate until very late in 2008 that the ZLB would be a binding constraint on monetary policy. Figure 5

3. See Brayton and others (1997) for a description of the FRB/US model. In the counterfactual simulations in this paper, I use the version of FRB/US with vector autoregressive expectations. In the stochastic simulations used to evaluate alternative policy rules discussed in sections II and III, I use the version of FRB/US with rational expectations. 
Figure 5. Federal Funds Rate, Actual 2003-08 and Forecast 2008-11

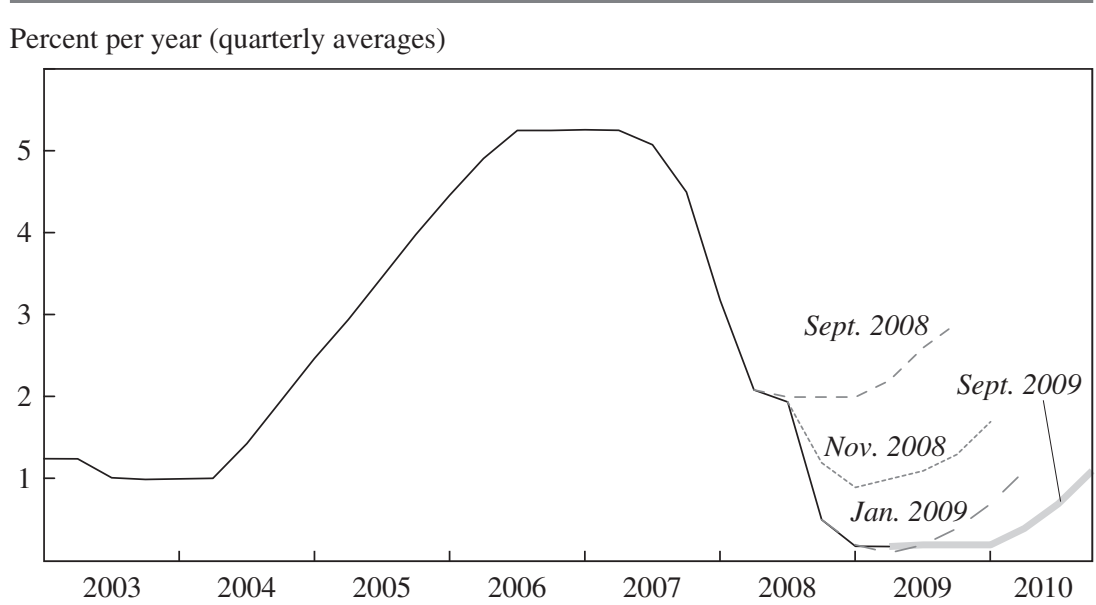

Sources: Blue Chip Financial Forecasts, various issues; Board of Governors of the Federal Reserve System, table H.15, "Selected Interest Rates," various issues.

a. Faded lines are Blue Chip forecasts as of the indicated date.

uses the consensus forecast reported in Blue Chip Financial Forecasts to show the expected path of the federal funds rate at various points in 2008 and 2009. At the beginning of September 2008 - right before the failure of the investment bank Lehman Brothers and the ensuing panic-forecasters did not expect the funds rate to fall below 2 percent. It was not until early December 2008, when the full ramifications of the panic became clear, that forecasters came to anticipate a sustained period of rates below 1 percent, and the ZLB clearly came into play. In fact, the FOMC cut the target funds rate from 1 percent to a range of zero to $1 / 4$ percentage point on December 16 , 2008. A similar pattern is seen in forecasts of policy rates in other major industrial economies, whose central banks made their final rate cuts in December 2008 or in 2009.

The preceding argument is based on evidence from point forecasts, which typically correspond to modal forecasts. But in theory, economic decisions depend on the full distribution of the relevant forecasts, not just the mode. The possibility that the ZLB could bind in the future may have introduced significant downward asymmetry in forecast distributions of output and inflation in late 2008. Such an increase in the tail risk of a severe recession could have caused households and businesses to curtail spending more than they would have if the ZLB had not been looming on the horizon. Although the evidence is not definitive, forecasts in late 2008 do not appear 
to provide much support for such a channel. Prices for binary options on the federal funds target rate indicate that even as late as early November 2008 , market participants placed only about a 25 percent probability on a target rate of 50 basis points or lower in January 2009. ${ }^{4}$ In addition, the distribution of forecasts for real GDP growth in 2009 from the Survey of Professional Forecasters (SPF) in the fourth quarter of 2008 does not display obvious signs of asymmetric downside risks.

In summary, the available evidence suggests that through late 2008, that is, until the ramifications of the financial panic following the failure of Lehman Brothers were recognized, forecasters did not view the ZLB as a binding constraint on policy. Therefore, it is unlikely that it had a significant impact on the major industrial economies before that time, outside Japan. Importantly, this is the period in which these economies were contracting most rapidly. According to monthly figures constructed by Macroeconomic Advisers, the period of sharply declining real U.S. GDP ended in January 2009, with declines of 2 percent in December 2008 and 0.7 percent in January 2009. Real GDP was roughly flat from January through July 2009.

Since early 2009 , however, the ZLB has clearly been a constraint on monetary policy in the United States and abroad. Interestingly, forecasters and market participants expect that the ZLB will pose a relatively shortlived problem outside Japan. The dashed extensions of the lines in figure 1 show market expectations of overnight interest rates derived from interest rate futures contracts as of September 2009. At that time market participants expected major central banks except the Bank of Japan to start raising rates by early 2010. As shown in figure 5, the Blue Chip forecasters have likewise consistently predicted that the Federal Reserve would start raising rates after about a year of near-zero rates. Even those forecasters in the bottom tail of the distribution of the Blue Chip panel expected the ZLB to constrain policy for only about a year and a half. Based on these expectations that central banks will raise rates relatively soon, one might be tempted to conclude that the effects of the ZLB have been relatively modest. Arguing against that conclusion is the fact that four quarters is the mean duration that the ZLB constrained policy in the model simulations with a 2 percent inflation target reported in Reifschneider and Williams (2000), and that even such relatively brief episodes can inflict costs on the

4. See Carlson, Craig, and Melick (2005) for a discussion of the methodology of computing probabilities from option prices. 
macroeconomy. Moreover, these forecasts of the path of interest rates may prove inaccurate.

I construct my counterfactual simulations starting from a baseline forecast set equal to the August 2009 SPF forecast (Federal Reserve Bank of Philadelphia 2009). The baseline forecast and the counterfactual simulations for short-term interest rates, the unemployment rate, and inflation (as measured by the core price index for personal consumption expenditure, PCE) are shown in figure $6 .{ }^{5}$ The SPF foresees the unemployment rate remaining above 7 percent through 2012 and core PCE inflation remaining below the median value of the FOMC's long-run inflation forecasts of 2 percent through 2011. Interestingly, this forecast has the core inflation rate rising over 2010-11, despite continued high unemployment. Such a forecast is consistent with a Phillips curve model of inflation in which inflation expectations are well anchored around 2 percent (Williams 2009). Note that these forecasts incorporate the effects of the fiscal stimulus and unconventional monetary policy actions taken in the United States and abroad.

I consider three alternative paths for the nominal federal funds rate and examine the resulting simulated values of the unemployment rate and the core PCE inflation rate. Given the evidence presented above that the ZLB was not a binding constraint until the very end of 2008, I assume in these counterfactual scenarios that additional nominal rate cuts of 200,400 , and 600 basis points occur in 2009Q1. I assume that the entire additional cut occurs in that quarter and that rates are held below the baseline values through 2010Q4, after which the short-term nominal rate returns to its baseline (SPF forecast) value. I assume no modifications of the discretionary fiscal policy actions and unconventional monetary policy actions that are assumed in the baseline forecast. I further assume that the monetary transmission mechanism works as predicted by the FRB/US model; that is, that the disruptions in the financial sector do not change the marginal effect of the additional rate cuts. ${ }^{6}$ Admittedly, these are strong assumptions, but I do not see better alternatives.

5. Because the SPF does not provide a forecast for the federal funds rate, I use its forecast for the three-month Treasury bill rate as a proxy. In addition, the SPF does not report quarterly figures for 2011 and 2012. I therefore interpolate quarterly figures based on annual figures for those years and the multiyear forecasts for PCE inflation.

6. It can be argued that monetary policy may be more or less effective than usual in the current environment, but there is little empirical evidence to guide any modifications of the model. 
Figure 6. Baseline Federal Funds Rate Forecast and Counterfactual Simulations, 2008-12

Percent per year

\section{Short-term interest rates}

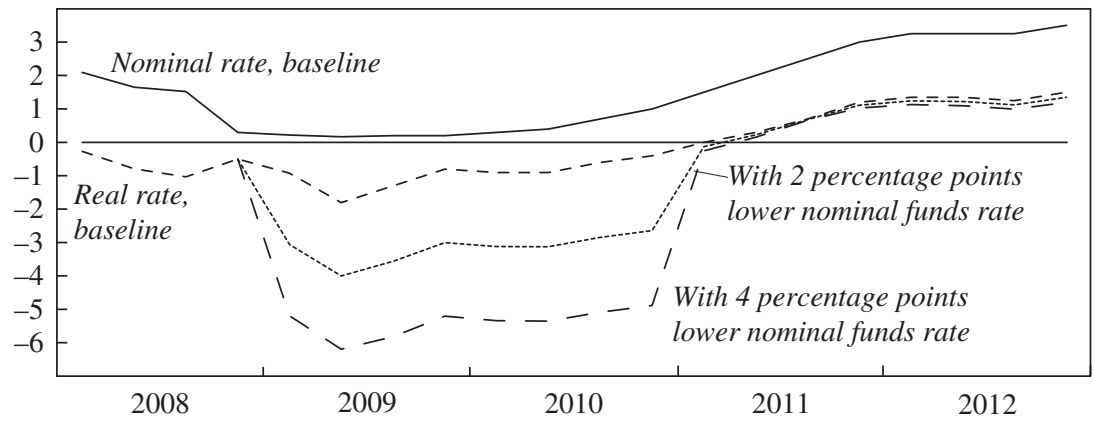

Percent

\section{Unemployment rate}

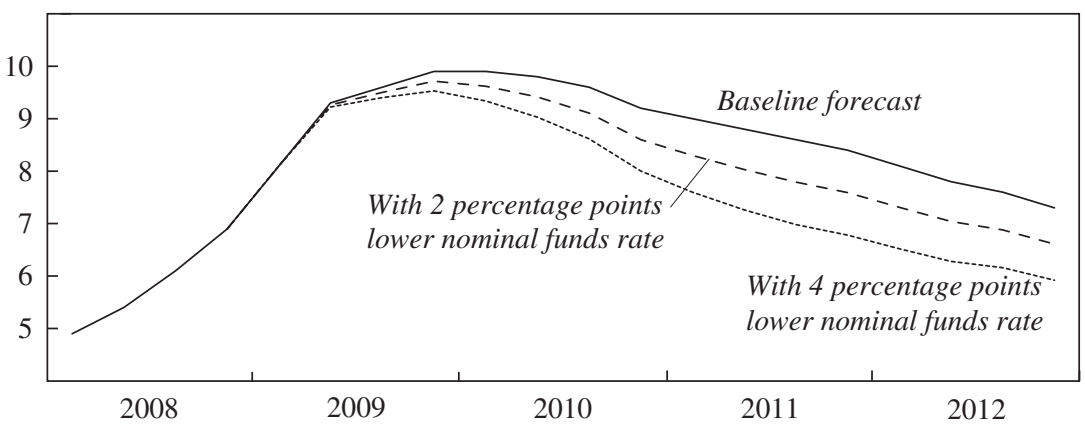

Percent

\section{Core PCE inflation}

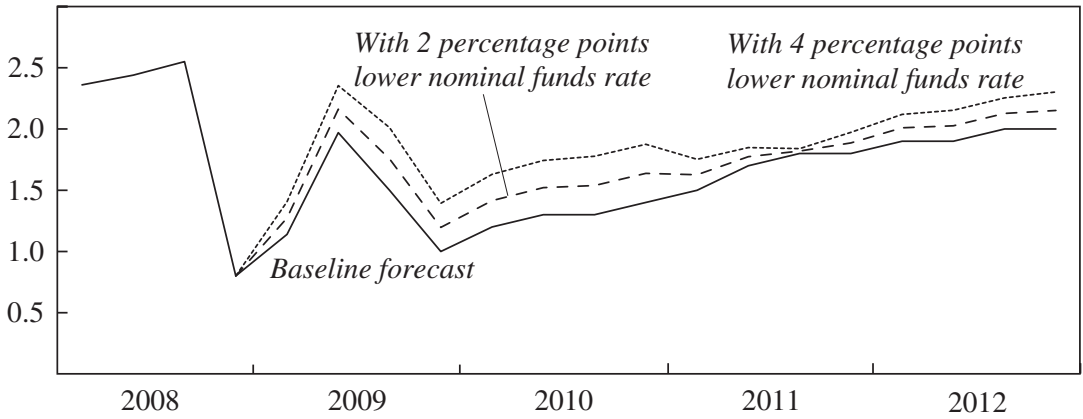

Sources: Survey of Professional Forecasters, August 2009; author's calculations. 
I evaluate the simulated outcomes using a standard ad hoc central bank loss function of the form

$$
L=\sum_{t=2009 q 1}^{2012 q^{4}}\left\{\left(\pi_{t}-2\right)^{2}+\lambda\left(u_{t}-u^{*}\right)^{2}\right\}
$$

where $\pi$ is the core PCE inflation rate, $u$ is the unemployment rate, and $u^{*}$ is the natural rate of unemployment. The inflation goal is assumed to be 2 percent. The SPF forecast runs only through late 2012, so I cannot extend the calculation of the loss beyond that point, nor can I use the optimal control techniques developed by Lars Svensson and Robert Tetlow (2005). Table 1 summarizes the outcomes for the baseline forecast and the alternative policy simulations. The first four columns report the central bank loss for different weights $\lambda$ on unemployment stabilization and different values for the natural rate of unemployment assumed in the loss function. ${ }^{7}$ These values for the natural rate cover the range of recent estimates. For example, the median estimate in the most recent SPF survey was 5 percent, and the highest reported estimate was 6 percent. Justin Weidner and Williams (2009) provide evidence suggesting that the output gap is smaller than standard estimates. After taking into account the historical relationship between the output gap and the unemployment gap, they calculate an average estimate of the output gap that suggests that the natural rate of unemployment may currently be as high as 7 percent. The final two columns of table 1 report the simulated values of the unemployment and inflation rates at the end of the forecast period (2012Q4).

Cutting the federal funds rate by an additional 200 basis points (second row of table 1) speeds the pace of economic recovery relative to the baseline forecast, bringing the unemployment rate to near $6 \frac{1}{2}$ percent by the end of 2012. Meanwhile the reduction in slack and the lower exchange value of the dollar cause core price inflation to rise more quickly back to 2 percent. In fact, core inflation slightly overshoots 2 percent by the end of 2012. This policy reduces the central bank loss function by a considerable amount for all combinations of parameters reported in the table. In the baseline forecast, inflation is below target for nearly the entire forecast period, and the unemployment rate is consistently above the natural rate, so the added

7. Note that I assume the same baseline forecast independent of the value of the natural rate of unemployment used in computing the central bank loss. That is, I treat the natural rate as an unobservable variable that underlies the baseline forecast. In particular, I do not consider alternative baseline forecasts predicated on alternative views of the natural rate. 


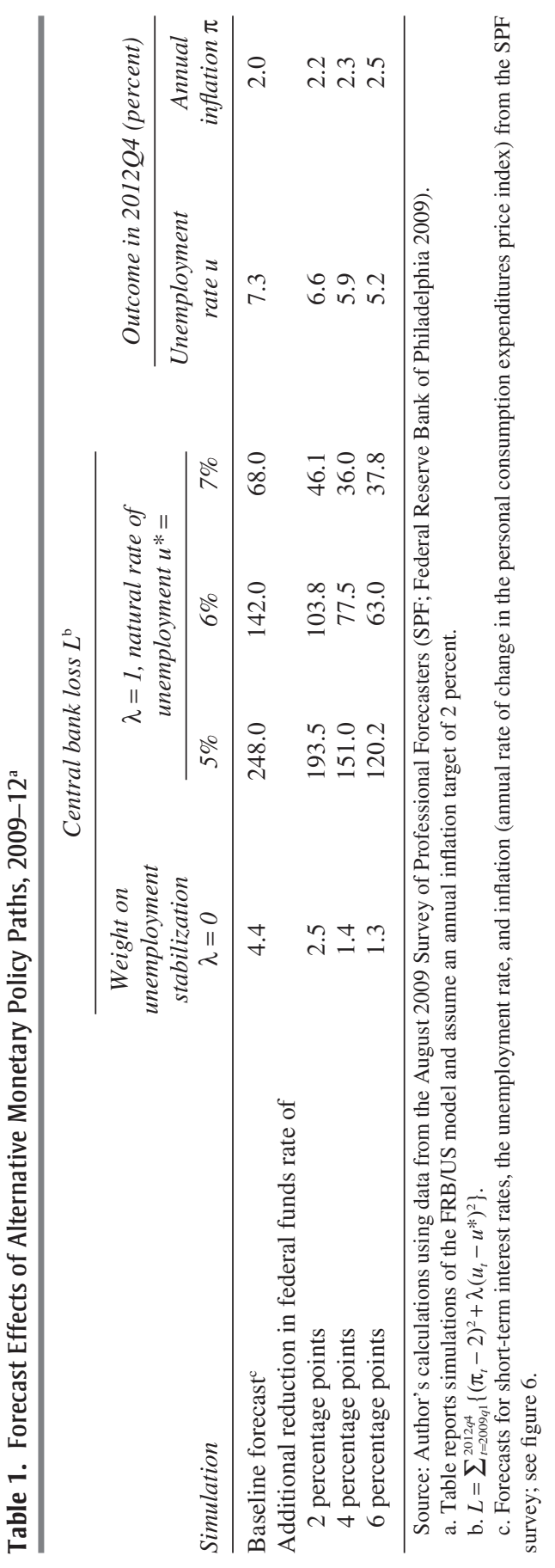


200 basis points of rate cuts moves both objective variables closer to target. Only in the final few quarters of the simulation do trade-offs materialize. Policy would need to be tightened at some point to bring inflation back down to 2 percent. Of course, in all cases the appropriate path for policy in 2012 and beyond depends on the natural rate of unemployment and the path of the economy in later years.

The second simulation, which assumes 400 basis points of easing relative to baseline, is more effective at bringing the unemployment rate down and inflation closer to the assumed 2 percent target over most of the forecast period. This policy yields a much lower central bank loss for all parameter combinations reported in the table. The results are striking. Even when the sole objective is the stabilization of inflation $(\lambda=0)$, an additional 400 basis points of easing is called for. When the central bank also cares about stabilizing unemployment around its natural rate $(\lambda=1.0), 400$ basis points of easing reduces the central bank loss even with a 7 percent natural rate of unemployment.

The third simulation of 600 basis points of easing relative to baseline yields mixed results. It results in a smaller loss over the simulation period as long as the natural rate of unemployment is below 7 percent. But it accomplishes this at the cost of an inflation rate that is $1 / 2$ percentage point above the assumed target at the end of 2012. Given these results, such a sharp reduction in rates would be beneficial only if the natural rate of unemployment is not much higher than 5 percent and if it were followed by a much sharper increase in interest rates in 2011 and 2012 than assumed in the simulation.

Based on these results, a compelling case can be made that at least an additional 400 basis points of rate reduction in early 2009 would have been beneficial in terms of stabilizing inflation around a 2 percent target, and unemployment around its natural rate. The cost of the ZLB in this episode can be measured as the difference in real output between the baseline forecast and the alternative simulation of an additional 400 basis points of rate cuts. In that simulation, real GDP averages about 3 percent above the baseline forecast over 2009-12 (the unemployment rate averages about 1 percentage point below baseline over this period). An additional 4 percentage points of monetary stimulus thus yields a total increase in output over these four years of about $\$ 1.8$ trillion. This translates into an increase in output per capita totaling about $\$ 5,700$ over these four years. The implied increase in consumption is about 2 percent, on average, which translates into a total increase in consumption per capita of about $\$ 2,700$ over the same period. (These calculations ignore any additional effects on output 
outside the forecast window.) By any measure, these are sizable losses from the ZLB and much larger than standard estimates of the cost of business cycle fluctuations. ${ }^{8}$

A final caveat is in order. A notable feature of these alternative scenarios is that they entail sizable negative real interest rates for two years. In the second alternative scenario of a 400-basis-point reduction in interest rates, the real funds rate averages below -5 percent during 2009 and 2010. As shown in figure 4 , there have been few peacetime episodes of large, sustained negative real interest rates. Although clearly helpful from the perspective of stimulating the economy, such a lengthy period of very negative real rates could have harmful unintended consequences, such as fueling another speculative boom-and-bust cycle (see, for example, Taylor 2007).

\section{Reexamining the Lessons from Research}

These simulations illustrate the large costs associated with the ZLB in the current situation. However, if this recession represents a unique, extraordinary incident, it has no implications for the choice of inflation goal or design of a policy rule regarding the ZLB. Indeed, a third "lesson" from Reifschneider and Williams (2000) is that only in rare instances will the ZLB be very destructive to the macroeconomy, requiring fiscal or other policies to avoid a complete economic collapse. The recent episode-characterized by reckless risk taking on a global scale, poor risk management, lax regulatory oversight, and a massive asset bubble — may be such a 100-year flood. Alternatively, this episode may have exposed some cracks in the analysis of the ZLB's effects on the ability of central banks to achieve their macroeconomic stabilization goals. In this section I review some key assumptions from the literature and conduct "stress tests" of past research, applying lessons from the past few years.

The magnitude of the welfare loss owing to the ZLB depends critically on four factors: the model of the economy, the steady-state nominal interest rate buffer (equal to the sum of the steady-state inflation rate, $\pi^{*}$, and the steady-state, or "equilibrium," real interest rate, $\left.r^{*}\right)$, the nature of the disturbances to the economy, and the monetary and fiscal policy regime. Recent events have challenged a number of assumptions regarding the structure of the macroeconometric models used in past research on the ZLB. Eventually,

8. The current episode, as projected by the SPF forecast, is an outlier in both depth and duration compared with earlier post-World War II recessions. But as argued in this paper, the ZLB has played a key role in this outcome, a situation that has not occurred since the Great Depression. 
new models will emerge from the experience of the past few years, but for now I am limited to the models that exist. ${ }^{9}$ Because the effects of the ZLB depend on the extent of nominal and real frictions (Coenen 2003) and the full set of shocks buffeting the economy, quantitative research into the effects of the ZLB is best done with richer models that incorporate such frictions. For this reason, in this paper I use the Federal Reserve Board's FRB/US model for my analysis, rather than a small-scale stylized model.

One critical aspect of model specification is the assumption that inflation expectations remain well anchored when the ZLB is binding. As discussed in Reifschneider and Williams (2000) and in George Evans, Eran Guse, and Seppo Honkapohja (2008), if inflation expectations are not anchored, the ZLB could give rise to a calamitous deflationary spiral, with rising rates of deflation sending real interest rates soaring and the economy into a tailspin. In the event, inflation expectations have been remarkably well behaved in all major industrial economies. The dashed extensions of the lines in figure 3 show consensus forecasts of overall inflation in several countries. Despite the severity of the downturn, forecasters expect inflation rates to bounce back over this year and next. Long-run inflation expectations in these countries, shown in figure 7 , have also been very stable over the past several years, despite the large swings in commodity prices and the severe global recession. Thus far, at least, inflation expectations appear well anchored. But there remains a risk that they could become unmoored, in which case the ZLB poses a larger threat.

A second key assumption is the steady-state real interest rate, which, along with the steady-state inflation rate, provides the buffer for monetary policy actions to stabilize the economy. A worrying development over the past decade is the decline in real interest rates. In the United States, the long-run average of the real interest rate-defined as the nominal federal funds rate less the PCE inflation rate-is about $2 \frac{1}{2}$ percent, the figure used by Reifschneider and Williams (2000). But the Kalman filter estimate of the equilibrium real interest rate, using the Laubach and Williams (2003) model, has fallen to about 1 percent, as shown in figure 8. Other time series-based estimates show similar or even larger declines. For example, the trend real interest rate computed using a Hodrick-Prescott filter (with a smoothing parameter of 1600) was around zero in the second quarter of 2009.

As shown in figure 8, the decline in the Kalman filter estimate of the equilibrium real interest rate coincided with the recent severe downturn

9. Beyond the need for better models of financial frictions, the global nature of the crisis has important implications for the effects of the ZLB and the ability of monetary policy to stabilize the economy (Bodenstein, Erceg, and Guerrieri 2009). 
Figure 7. Long-Run Inflation Expectations in Major Industrial Countries, 2000-April 2009

Percent per year

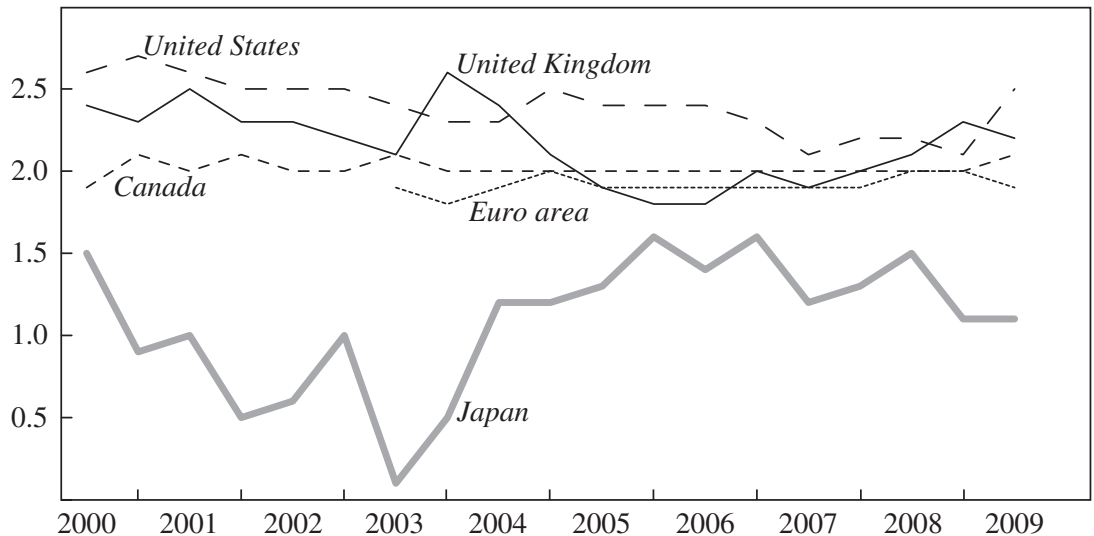

Source: Consensus Economics, "Consensus Forecasts," 2000-April 2009, April and October issues.

Figure 8. Estimates of Equilibrium Real Short-Term Interest Rates, 1975-2009

Percent per year

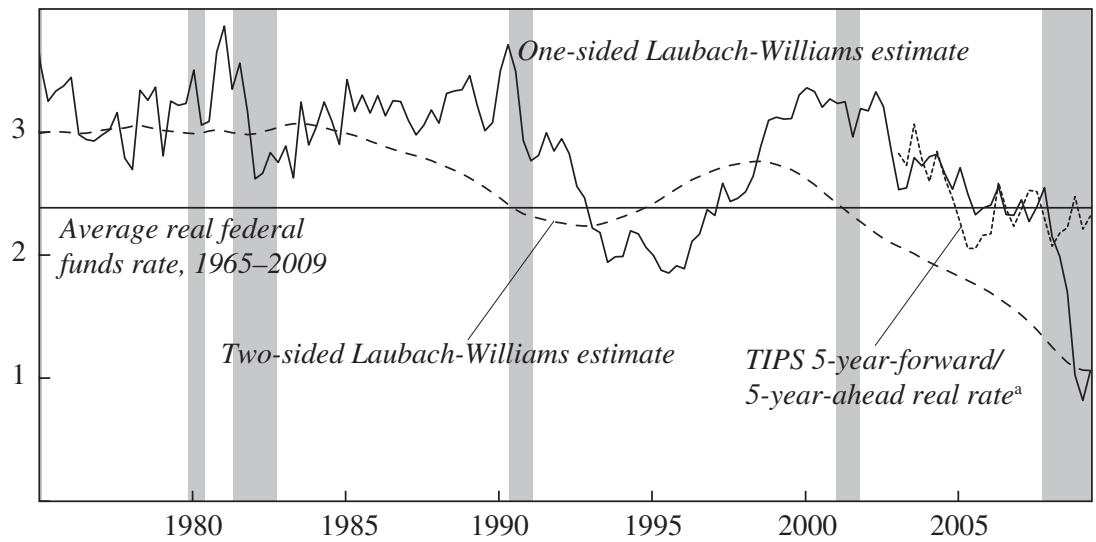

Sources: Board of Governors of the Federal Reserve System, table H.15, "Selected Interest Rates," various issues; Bureau of Economic Analysis data; author's calculations.

a. TIPS, Treasury inflation-protected securities. 
and may prove to be an overreaction to it. This hypothesis receives some support from prices of inflation-indexed Treasury securities. Evidently, investors expect real interest rates to remain low over the next five years but to be closer to historically normal levels thereafter. Nonetheless, the massive loss in wealth and high levels of household debt both in the United States and abroad could cause a sizable increase in private saving (Glick and Lansing 2009). All else equal, such an increase in saving would imply that the steady-state real interest rate will remain low for some time. Based on this evidence, a reasonable point estimate of the steady-state real federal funds rate is about $2 \frac{1}{2}$ percent, but the risk is real that it could be as low as 1 percent. Of course, the steady-state real rate could be higher than $2 \frac{1}{2}$ percent, possibly owing to large fiscal deficits in the United States and abroad (Laubach 2009). In that case the effects of the ZLB would be correspondingly muted.

The third key assumption concerns the nature of future disturbances to the economy. Because the ZLB affects events in the lower tail of the distribution of interest rates, the distribution of shocks is a critical factor determining its effects. Reifschneider and Williams (2000; FOMC 2002) based their analysis on the covariance of estimated disturbances from the mid-1960s through the mid-1990s. Other research is based on disturbances from the period of the Great Moderation from the early 1980s on (Coenen, Orphanides, and Wieland 2004; Adam and Billi 2006; Williams 2006). Recent events hint that what were once thought to be negative "tail" events may occur frequently, and that the period of the Great Moderation may suggest an overly optimistic view of the future macroeconomic landscape. Given the limited number of observations since the start of the financial crisis, one cannot yet ascertain whether these events represent a sustained break from the past behavior of disturbances.

Given the great deal of uncertainty-much of it difficult or even impossible to quantify - regarding the future economic environment, I take a minimax approach to evaluating policies. Specifically, I look for policies that perform well in very adverse or "worst-case" scenarios as well as in the baseline scenario. I take the baseline scenario to be a steady-state real interest rate of $2 \frac{1}{2}$ percent, and I consider disturbances drawn from a joint normal distribution based on model disturbances from 1968 to 2002. I consider alternative adverse scenarios characterized by a steady-state real interest rate of 1 percent and disturbances drawn from more adverse distributions. Of course, these two sources of uncertainty represent only a slice of the spectrum of uncertainty relevant for the ZLB. By taking worst cases from these two sources, my aim is to provide insurance against a wide 
variety of other forms of uncertainty, including model misspecification and unanchored inflation expectations.

I follow the simulation methodology of Reifschneider and Williams (2000), with two relatively minor modifications. First, the simulation results reported here are based on a more recent vintage of the FRB/US model from 2004. Second, following Athanasios Orphanides and others (2000) and Reifschneider and Williams (FOMC 2002), I assume that the output gap included in the monetary policy rule is subject to exogenous, serially correlated mismeasurement. The estimates of the simulated moments are based on two sets of stochastic simulations, encompassing 25,000 years of simulated data. ${ }^{10}$ The use of such extremely long simulations provides reasonably accurate estimates of model-implied moments, effectively eliminates the effects of initial conditions, and ensures that rare events will occur in the simulations. Finally, I assume that automatic stabilizers and other endogenous responses of fiscal variables behave as usual, but that discretionary fiscal policy is not used except in extreme downturns.

In what follows, unless otherwise indicated, monetary policy is assumed to follow a Taylor-type policy rule of the form

$$
i_{t}=\max \left\{0, r_{t}^{*}+\bar{\pi}_{t}+0.5\left(\bar{\pi}_{t}-\pi^{*}\right)+\varphi y_{t}\right\},
$$

where $i_{t}$ is the nominal interest rate, $r_{t}^{*}$ is the steady-state real interest rate, $\bar{\pi}_{t}$ is the four-quarter percent change in the PCE price index, $\pi^{*}$ is the inflation target, and $y_{t}$ is the output gap. ${ }^{11}$ Following Orphanides and Williams (2002), I refer to the specification with $\varphi=0.5$ as the "classic" Taylor (1993) rule; I refer to other specifications as "Taylor-type" rules.

The simulated outcomes are evaluated using a slightly different central bank loss function from that used earlier, of the form

$$
L=\mathrm{E}\left\{\left(\pi-\pi^{*}\right)^{2}+y^{2}+0.25 *\left(i-i^{*}\right)^{2}\right\},
$$

where $\pi$ is the overall PCE inflation rate, $i^{*}=\pi^{*}+r^{*}$ is the unconditional mean of the nominal short-term interest rate, and $\mathrm{E}$ denotes the unconditional

10. In the analyses using disturbances following the $t$ distribution, I conduct twice as many simulations as in the analyses using normally distributed disturbances.

11. I have included an upward bias in the notional inflation target in the policy rule that is needed for the inflation rate to equal the true target level. As discussed in Reifschneider and Williams (2002) and Coenen, Orphanides, and Wieland (2004), the asymmetric nature of the ZLB implies that the inflation rate will on average be lower than the inflation target in the rule. This upward bias is larger, the more the ZLB constrains policy. I correct for this downward bias by adjusting the inflation target in the policy rule. 
expectation. Note that I consider only the costs of inflation variability and not the costs of steady-state inflation, on the grounds that current understanding of the costs of steady-state inflation is very limited. ${ }^{12}$ Thus, I stop short of finding optimal inflation targets. I return to the issue of the costs of steady-state inflation briefly in the concluding section.

The top panel of table 2 reports the simulated outcomes under the classic Taylor rule, assuming the shocks are drawn using a normal distribution from the covariance matrix computed from the full sample of disturbances (1968-2002). In terms of the model simulations, the key statistic is the nominal interest rate buffer, which equals the sum of the steady-state inflation rate and the steady-state real interest rate. The first two columns list steady-state inflation rates corresponding to alternative values of $r^{*}$ of $2 \frac{1}{2}$ percent (the baseline scenario) and 1 percent, respectively. The third and fourth columns report, for each of these combinations of steady-state inflation and interest rates, the share of the time that the nominal federal funds rate is below 0.1 and 1 percent, respectively. The fifth column reports for each combination the share of the time that the output gap is below -4 percent, representing the trough of a major recession of the type that has occurred in 1958, 1975, 1982-83, and 2009. (For comparison, over 1955Q1-2009Q2, the Congressional Budget Office's estimate of the output gap was below -4 percent about 6 percent of the time.) The sixth through eighth columns report the corresponding standard deviations of the output gap, the PCE inflation rate, and the nominal federal funds rate. The final column reports the central bank loss.

In the baseline scenario, if policy follows the classic Taylor rule, then the ZLB has only minor effects on the magnitude of macroeconomic fluctuations if the inflation target is $1 \frac{1}{2}$ percent or higher. Under these assumptions, a $1 \frac{1}{2}$ percent inflation target implies that the funds rate will fall below 1 percent 10 percent of the time, and will be below 10 basis points 6 percent of the time. The standard deviation of the unconstrained funds rate is only about $2 \frac{1}{2}$ percent. So, with a 4 -percentage-point buffer, most episodes where the ZLB is binding are relatively mild, and the effects are minor. These results are consistent with those of many studies finding that with a steady-state nominal interest rate of 4 percent or higher, the ZLB has very modest macroeconomic effects under the Taylor rule.

12. Alternatively, this approach can be justified by assuming that firms increase prices at the steady-state inflation rate without incurring adjustment costs (in an adjustment cost model) or reoptimizing (in a Calvo model). 
Table 2. Simulated Outcomes under a Classic Taylor Rule for Different Shock Distributions

\begin{tabular}{|c|c|c|c|c|c|c|c|c|}
\hline \multicolumn{2}{|c|}{$\begin{array}{l}\text { Annual inflation } \\
\text { target } \pi * \text { (percent) } \\
\text { corresponding to the } \\
\text { indicated steady-state } \\
\text { real interest rate } r^{* a}\end{array}$} & \multicolumn{2}{|c|}{$\begin{array}{l}\text { Percent of the time } \\
\text { the federal funds } \\
\text { rate } i \text { will be below } \\
\text { the indicated value }\end{array}$} & \multirow{2}{*}{$\begin{array}{l}\text { Percent of } \\
\text { the time } \\
\text { the output } \\
\text { gap will be } \\
\text { below }-4 \%\end{array}$} & \multicolumn{3}{|c|}{$\begin{array}{l}\text { Standard } \\
\text { deviations of the } \\
\text { output gap } y \text {, } \\
\text { inflation } \pi \text {, and } \\
\text { the federal } \\
\text { funds rate } i\end{array}$} & \multirow{2}{*}{$\begin{array}{c}\text { Central } \\
\text { bank } \\
\text { loss } L^{\mathrm{b}}\end{array}$} \\
\hline$r^{*}=2.5 \%$ & $r^{*}=1.0 \%$ & $i=0.1 \%$ & $i=1.0 \%$ & & $y$ & $\pi$ & $i$ & \\
\hline \multicolumn{9}{|c|}{ Shocks drawn from 1968-2002 covariance, normal distribution } \\
\hline-0.5 & 1 & 23 & 31 & 12 & 3.1 & 1.5 & 2.4 & 13.3 \\
\hline 0.5 & 2 & 13 & 20 & 8 & 2.8 & 1.5 & 2.4 & 11.5 \\
\hline 1.5 & 3 & 6 & 10 & 6 & 2.6 & 1.5 & 2.5 & 10.6 \\
\hline 2.5 & 4 & 4 & 8 & 6 & 2.6 & 1.5 & 2.6 & 10.5 \\
\hline 3.5 & 5 & 2 & 3 & 6 & 2.5 & 1.5 & 2.6 & 10.1 \\
\hline 5.5 & 7 & 0 & 0 & 5 & 2.5 & 1.5 & 2.6 & 9.9 \\
\hline 7.5 & 9 & 0 & 0 & 5 & 2.5 & 1.5 & 2.6 & 9.9 \\
\hline \multicolumn{9}{|c|}{ Shocks drawn from 1968-2002 covariance, $\mathrm{t}$ distribution with 5 degrees of freedom } \\
\hline-0.5 & 1 & 24 & 33 & 13 & 3.1 & 1.5 & 2.4 & 13.2 \\
\hline 0.5 & 2 & 13 & 20 & 8 & 2.8 & 1.5 & 2.5 & 11.5 \\
\hline 1.5 & 3 & 8 & 13 & 7 & 2.7 & 1.5 & 2.5 & 10.8 \\
\hline 2.5 & 4 & 4 & 7 & 6 & 2.6 & 1.5 & 2.7 & 10.6 \\
\hline 3.5 & 5 & 3 & 5 & 6 & 2.6 & 1.5 & 2.7 & 10.6 \\
\hline 5.5 & 7 & 0 & 0 & 5 & 2.5 & 1.5 & 2.6 & 9.9 \\
\hline 7.5 & 9 & 0 & 0 & 5 & 2.5 & 1.5 & 2.6 & 9.9 \\
\hline \multicolumn{9}{|c|}{ Shocks drawn from 1968-83 covariance, normal distribution } \\
\hline-0.5 & 1 & 29 & 38 & 18 & 3.7 & 1.7 & 2.6 & 18.4 \\
\hline 0.5 & 2 & 16 & 23 & 12 & 3.3 & 1.6 & 2.8 & 15.5 \\
\hline 1.5 & 3 & 9 & 14 & 11 & 3.2 & 1.6 & 2.8 & 14.5 \\
\hline 2.5 & 4 & 4 & 7 & 9 & 3.0 & 1.6 & 2.8 & 13.6 \\
\hline 3.5 & 5 & 3 & 6 & 9 & 2.9 & 1.6 & 2.9 & 13.4 \\
\hline 5.5 & 7 & 2 & 3 & 8 & 2.9 & 1.6 & 2.9 & 13.0 \\
\hline 7.5 & 9 & 0 & 0 & 8 & 2.9 & 1.6 & 2.9 & 13.0 \\
\hline
\end{tabular}

Source: Author's calculations.

a. The monetary policy rule is assumed to be $i_{t}=\max \left\{0, r_{t}^{*}+\bar{\pi}_{t}+0.5\left(\bar{\pi}_{t}-\pi^{*}\right)+0.5 y_{t}\right\}$.

b. $L=\mathrm{E}\left\{\left(\pi-\pi^{*}\right)^{2}+y^{2}+0.25^{*}\left(i-i^{*}\right)^{2}\right\}$, where $i^{*}=\pi^{*}+r^{*}$.

If instead the steady-state real interest rate is only 1 percent, then under the classic Taylor rule a 3 percent inflation objective is still sufficiently high to avoid most costs from the ZLB. But with a 2 percent inflation goal, the ZLB binds 13 percent of the time and causes a more noticeable rise in output gap variability: a rise of 0.3 percentage point relative to an inflation goal of 5 percent or higher. The incidence of deep recessions rises as well but remains below 10 percent. Based on this evidence, a lower steady-state real interest rate argues for a higher inflation goal to 
reduce the costs associated with the ZLB. But it alone does not overturn the basic result of past research that a 2 percent inflation goal is associated with relatively modest costs from the ZLB. This conclusion is reinforced when one considers alternative policy rules that mitigate the problems associated with the ZLB, as discussed below.

As noted above, the assumption of normally distributed disturbances may understate the likelihood of tail events of the type recently experienced. To gauge the sensitivity of the results to this assumption, I conduct simulations where the disturbances have the same covariance as before (that is, based on the full 1968-2002 sample) but are assumed to follow the $t$ distribution with 5 degrees of freedom. This distribution is characterized by excess (relative to the normal distribution) kurtosis of 6; that is, it displays significantly fatter tails than the normal distribution. For example, the probability of a 3-standard-deviation (or greater) event is over four times greater with this $t(5)$ distribution than with the normal distribution. ${ }^{13}$

Allowing for a fatter-tailed distribution of disturbances does not materially affect the results regarding the effects of the ZLB (middle panel of table 2). The ZLB is encountered slightly more often, and the standard deviation of the output gap is in some cases higher, but these effects are nearly lost in rounding. Note that the shocks being considered differ from those in the other simulations; thus, comparison with the simulations using normally distributed disturbances is not exact because of the finite samples of the simulations. Similar results (not reported) were obtained when the disturbances were assumed to follow a Laplace distribution, which has excess kurtosis of 3. More exotic distributions with even greater kurtosis may exist that would have greater effects on these results, but a more critical issue appears to be the covariance of the shocks, rather than the precise shape of the distribution.

The effects of the ZLB are far more pronounced when the shocks are drawn from the pre-Great Moderation period. In the simulations reported in the bottom panel of table 2, the disturbances are drawn from a normal distribution where the covariance of disturbances is estimated from the 1968-83 sample. As a result, the ZLB is encountered more frequently and with greater costs in terms of stabilization of the output gap. With a steadystate real interest rate of $2 \frac{1}{2}$ percent, a 2 percent inflation target is just on the edge of the region where the ZLB has nontrivial costs in terms of macro-

13. The choice of 5 degrees of freedom is somewhat arbitrary but near the lower bound of allowable values for the purpose at hand. In particular, the degrees of freedom of the distribution must exceed 4 for finite second and fourth moments to exist. 
economic variability. Inflation goals of $1 \frac{1}{2}$ percent or lower entail moderate increases in output gap variability.

The combination of a 1 percent steady-state real interest rate and greater volatility of disturbances poses the greatest threat to macroeconomic stabilization in a low-inflation environment. In this case inflation goals of 2 to 3 percent are associated with some increase in output gap variability, and a 1 percent goal entails a significant increase. Yet even in these extreme cases, the effects on inflation variability are quite modest, reflecting the effects of the assumption of well-anchored expectations.

How big are these losses? One metric is the fraction of the time the output gap is below -4 percent. In the adverse environment of shocks drawn from the 1968-83 shock covariance and a steady-state real interest rate of 1 percent, this figure rises from 9 percent to 18 percent when the inflation target is reduced from 4 percent to 1 percent. The standard deviation of the output gap rises by 0.7 percentage point. For comparison, the standard deviation of the output gap during the Great Moderation period was 2 percentage points, according to Congressional Budget Office estimates. The comparable figure for 1965-80 was 2.7 percentage points. Thus, moving from a 4 percent inflation target to a 1 percent target yields an increase in output gap variability in these model simulations comparable to switching from the Great Moderation period to the $1965-80$ period. Moving from a 4 percent inflation target to a 2 percent target entails an increase in output gap variability comparable to switching from the Great Moderation period to the period from 1955 to 1965 , when the standard deviation of the output gap was 2.3 percentage points, or 0.3 percentage point above that during the Great Moderation period.

\section{Alternative Monetary and Fiscal Policies}

The results reported above indicate that in a particularly adverse macroeconomic environment of large shocks and a low steady-state real interest rate, the $\mathrm{ZLB}$ may cause a significant deterioration in macroeconomic performance when monetary policy follows the classic Taylor rule with a very low inflation target. As discussed in Reifschneider and Williams (2000; FOMC 2002) and Gauti Eggertsson and Michael Woodford (2003), alternative monetary policy strategies can improve upon the performance of the classic Taylor rule in a low-inflation environment. Several such modifications are examined here. In addition, I consider the use of countercyclical fiscal policy to mitigate the effects of the ZLB. Throughout the following discussion, I assume the worst-case adverse macroeconomic environment of a 1 percent steady-state real interest rate and disturbances 
drawn from the covariance matrix computed from the shocks of the pre-Great Moderation period.

\section{III.A. Modifying the Taylor Rule}

One way to achieve greater stabilization of the output gap even at low steady-state inflation rates and in an adverse environment is to have the policy rule respond more aggressively to movements in the output gap. Table 3 reports simulation results for alternative values of the coefficient

Table 3. Simulated Outcomes for Alternative Monetary Policy Responses to the Output Gapa

\begin{tabular}{|c|c|c|c|c|c|c|c|}
\hline \multirow{2}{*}{$\begin{array}{l}\text { Annual } \\
\text { inflation } \\
{\text { target } \pi^{*}}^{\text {(percent }^{\mathrm{b}}}\end{array}$} & \multicolumn{2}{|c|}{$\begin{array}{l}\text { Percent of the time the } \\
\text { federal funds rate } i \\
\text { will be below the } \\
\text { indicated value }\end{array}$} & \multirow{2}{*}{$\begin{array}{l}\text { Percent of } \\
\text { the time } \\
\text { the output } \\
\text { gap will be } \\
\text { below }-4 \%\end{array}$} & \multicolumn{3}{|c|}{$\begin{array}{l}\text { Standard deviations } \\
\text { of the output gap } y, \\
\text { inflation } \pi, \text { and the } \\
\text { federal funds rate } i\end{array}$} & \multirow[b]{2}{*}{ Loss $L^{\mathrm{c}}$} \\
\hline & $i=0.1 \%$ & $i=1.0 \%$ & & $y$ & $\pi$ & $i$ & \\
\hline \multicolumn{8}{|c|}{ Coefficient on the output gap in the monetary policy rule $\varphi=0.5$} \\
\hline 1 & 29 & 38 & 18 & 3.7 & 1.7 & 2.6 & 18.4 \\
\hline 2 & 16 & 23 & 12 & 3.3 & 1.6 & 2.8 & 15.5 \\
\hline 3 & 9 & 14 & 11 & 3.2 & 1.6 & 2.8 & 14.5 \\
\hline 4 & 4 & 7 & 9 & 3.0 & 1.6 & 2.8 & 13.6 \\
\hline 5 & 3 & 6 & 9 & 2.9 & 1.6 & 2.9 & 13.4 \\
\hline 7 & 2 & 3 & 8 & 2.9 & 1.6 & 2.9 & 13.0 \\
\hline 9 & 0 & 0 & 8 & 2.9 & 1.6 & 2.9 & 13.0 \\
\hline \multicolumn{8}{|c|}{ Coefficient on the output gap in the monetary policy rule $\varphi=1.0$} \\
\hline 1 & 34 & 41 & 17 & 4.6 & 2.1 & 2.6 & 27.3 \\
\hline 2 & 16 & 22 & 8 & 3.1 & 1.7 & 3.3 & 15.2 \\
\hline 3 & 11 & 15 & 6 & 2.7 & 1.6 & 3.4 & 13.1 \\
\hline 4 & 8 & 12 & 6 & 2.6 & 1.6 & 3.4 & 12.4 \\
\hline 5 & 6 & 10 & 6 & 2.5 & 1.6 & 3.5 & 12.0 \\
\hline 7 & 2 & 3 & 5 & 2.5 & 1.6 & 3.6 & 12.0 \\
\hline 9 & 0 & 1 & 5 & 2.5 & 1.6 & 3.6 & 12.0 \\
\hline \multicolumn{8}{|c|}{ Coefficient on the output gap in the monetary policy rule $\varphi=1.5$} \\
\hline 1 & 42 & 49 & 20 & 4.9 & 2.1 & 3.3 & 31.2 \\
\hline 2 & 24 & 30 & 9 & 2.9 & 1.7 & 3.8 & 17.1 \\
\hline 3 & 19 & 24 & 6 & 2.6 & 1.6 & 4.0 & 13.4 \\
\hline 4 & 17 & 22 & 6 & 2.5 & 1.6 & 4.0 & 12.8 \\
\hline 5 & 11 & 15 & 5 & 2.3 & 1.6 & 4.2 & 12.5 \\
\hline 7 & 5 & 7 & 4 & 2.3 & 1.7 & 4.4 & 13.0 \\
\hline 9 & 2 & 3 & 4 & 2.3 & 1.7 & 4.6 & 13.2 \\
\hline
\end{tabular}

Source: Author's calculations.

a. All simulations use shock covariance data for 1968-83 and assume a steady-state real interest rate $r$ * equal to 1 .

b. The monetary policy rule is assumed to be $i_{t}=\max \left\{0, r_{t}^{*}+\bar{\pi}_{t}+0.5\left(\bar{\pi}_{t}-\pi^{*}\right)+\varphi y_{t}\right\}$.

c. $L=\mathrm{E}\left\{\left(\pi-\pi^{*}\right)^{2}+y^{2}+0.25 *\left(i-i^{*}\right)^{2}\right\}$, where $i^{*}=\pi^{*}+r^{*}$. 
on the output gap, $\varphi$, in the monetary policy rule in equation 2 . A larger response to a widening output gap reduces output gap variability and allows the central bank to reach output and inflation goals, at some cost of interest rate variability, even at inflation goals as low as 2 percent. For example, assume the goal is to have outcomes like those under the classic Taylor rule $(\varphi=0.5)$ unconstrained by the ZLB, but with an inflation target of 2 percent. The Taylor-type rule with the stronger response to the output gap of $\varphi=1.5$ yields outcomes for output gap and inflation rate variability close to those of the unconstrained classic Taylor rule, at the cost of somewhat greater interest rate variability. Outcomes similar to that of the unconstrained classic Taylor rule can be achieved with an inflation goal of 3 percent by setting $\varphi=1.0$.

Interestingly, too strong a response to the output gap can be counterproductive at very low steady-state interest rates. This outcome likely reflects the asymmetry of the policy response resulting from the ZLB. When the output gap is positive, policy tightens sharply. But when the output gap is negative, the policy response may be truncated by the ZLB. This strongly asymmetric response causes output gap variability to rise at very low inflation rate targets in the adverse macroeconomic environment. A stronger response to inflation in the Taylor-type rule has little impact on the effects of the ZLB (not shown). ${ }^{14}$

None of these modified Taylor rules performs well with an inflation target of 1 percent in the adverse macroeconomic environment. In all three cases the standard deviation of the output gap rises sharply, and the fraction of the time that the output gap is below -4 percent is extremely high, between 17 and 20 percent. These figures decline dramatically when the inflation target is raised to 2 percent.

Other modifications to the Taylor-type rule can also be effective at offsetting the effects of the ZLB in low-inflation environments. The top two panels of table 4 report the results from a modified Taylor-type rule proposed by Reifschneider and Williams (2000). According to this policy rule, realized deviations of the interest rate from that prescribed by the rule owing to the ZLB are later offset by negative deviations of equal magnitude. Note that this does not necessarily imply that the central bank is promising to raise inflation above its target in the future, but only that it makes up for "lost monetary stimulus" by holding the interest rate low for a period after the ZLB no longer binds.

14. There are other reasons, however, for a stronger response to inflation, such as the better anchoring of inflation expectations in an economy with imperfect knowledge, as discussed in Orphanides and Williams $(2002,2007)$. 
Table 4. Simulated Outcomes for Alternative Monetary Policy Rules ${ }^{\mathrm{a}}$

\begin{tabular}{|c|c|c|c|c|c|c|c|}
\hline \multirow{2}{*}{$\begin{array}{l}\text { Annual } \\
\text { inflation } \\
\text { target } \pi^{*} \\
\text { (percent) }\end{array}$} & \multicolumn{2}{|c|}{$\begin{array}{l}\text { Percent of the time the } \\
\text { federal funds rate } i \\
\text { will be below the } \\
\text { indicated value }\end{array}$} & \multirow{2}{*}{$\begin{array}{l}\text { Percent of } \\
\text { the time } \\
\text { the output } \\
\text { gap will be } \\
\text { below }-4 \%\end{array}$} & \multicolumn{3}{|c|}{$\begin{array}{l}\text { Standard deviations } \\
\text { of the output gap } y, \\
\text { inflation } \pi \text {, and the } \\
\text { federal funds rate } i\end{array}$} & \multirow[b]{2}{*}{ Loss $L^{\mathrm{b}}$} \\
\hline & $i=0.1 \%$ & $i=1.0 \%$ & & $y$ & $\pi$ & $i$ & \\
\hline \multicolumn{8}{|c|}{ Classic Taylor rule with lagged adjustment $(\varphi=0.5)^{\mathrm{c}}$} \\
\hline 1 & 18 & 26 & 12 & 3.7 & 1.6 & 2.8 & 19.4 \\
\hline 2 & 12 & 19 & 10 & 3.2 & 1.6 & 2.8 & 14.7 \\
\hline 3 & 7 & 13 & 9 & 3.0 & 1.6 & 2.8 & 13.6 \\
\hline 4 & 4 & 8 & 8 & 3.0 & 1.6 & 3.0 & 13.7 \\
\hline 5 & 3 & 5 & 8 & 2.9 & 1.6 & 2.9 & 13.0 \\
\hline 7 & 0 & 1 & 8 & 2.9 & 1.6 & 2.9 & 13.0 \\
\hline 9 & 0 & 0 & 8 & 2.9 & 1.6 & 2.9 & 13.0 \\
\hline \multicolumn{8}{|c|}{ Taylor-type rule with lagged adjustment $(\varphi=1.0)^{\mathrm{c}}$} \\
\hline 1 & 32 & 40 & 12 & 3.6 & 1.6 & 3.2 & 27.6 \\
\hline 2 & 21 & 28 & 7 & 2.9 & 1.6 & 3.4 & 13.6 \\
\hline 3 & 16 & 22 & 6 & 2.5 & 1.6 & 3.4 & 11.7 \\
\hline 4 & 5 & 15 & 6 & 2.5 & 1.6 & 3.5 & 11.7 \\
\hline 5 & 2 & 9 & 6 & 2.5 & 1.6 & 3.5 & 11.8 \\
\hline 7 & 0 & 3 & 5 & 2.5 & 1.6 & 3.6 & 12.0 \\
\hline 9 & 0 & 1 & 5 & 2.5 & 1.6 & 3.6 & 12.0 \\
\hline \multicolumn{8}{|c|}{ Optimized inertial policy rule $\mathrm{d}$} \\
\hline 1 & 24 & 33 & 10 & 3.4 & 1.4 & 2.4 & 14.5 \\
\hline 2 & 15 & 22 & 8 & 2.9 & 1.4 & 2.6 & 11.9 \\
\hline 3 & 11 & 16 & 7 & 2.7 & 1.4 & 2.6 & 11.0 \\
\hline 4 & 5 & 8 & 6 & 2.5 & 1.4 & 2.6 & 10.2 \\
\hline 5 & 2 & 4 & 6 & 2.5 & 1.4 & 2.7 & 10.1 \\
\hline 7 & 0 & 1 & 6 & 2.5 & 1.4 & 2.7 & 10.2 \\
\hline 9 & 0 & 0 & 6 & 2.5 & 1.4 & 2.7 & 10.2 \\
\hline
\end{tabular}

Source: Author's calculations.

a. All simulations use shock covariance data for 1968-83 and assume a steady-state real interest rate $r^{*}$ equal to 1 . Alternative monetary policies are described in the text.

b. $L=\mathrm{E}\left\{\left(\pi-\pi^{*}\right)^{2}+y^{2}+0.25^{*}\left(i-i^{*}\right)^{2}\right\}$, where $i^{*}=\pi^{*}+r^{*}$.

c. The policy rule is as described in Reifschneider and Williams (2000), in which realized deviations of the interest rate from that prescribed by the rule owing to the ZLB are later offset by opposite deviations of equal magnitude.

d. The policy rule is $i_{t}^{u}=0.96 i_{t-1}^{u}+0.04 *\left(r^{*}+\hat{\pi}_{t}\right)+0.04\left(\bar{\pi}_{t}-\pi^{*}\right)+0.12 y_{t}$.

This modified rule nearly eliminates the effects of the ZLB for inflation targets as low as 3 percent, and it significantly reduces them for lower inflation targets. If the inflation goal is 2 percent, the modified rule with a greater response to the output gap of $\varphi=1.0$ yields the same outcomes as the unconstrained Taylor rule in this adverse environment.

In rational expectations models like FRB/US, policies with inertial responses to movements in inflation and output gaps perform much better 
than static Taylor-type rules and closely approximate the outcomes under fully optimal policies (Woodford 2003; Levin and Williams 2003). The key benefit of inertial rules is that they generate expectations of the future path of policy that reinforce the direct effects of the policy actions on the economy. Here I examine the performance of an inertial policy rule taking the form

$$
i_{t}^{u}=0.96 i_{t-1}^{u}+0.04\left(r^{*}+\bar{\pi}_{t}\right)+0.04\left(\bar{\pi}_{t}-\pi^{*}\right)+0.12 y_{t},
$$

where $i_{t}^{u}$ is the prescription for the federal funds rate unconstrained by the ZLB. The coefficient on the lagged funds rate, at near unity, imparts a great deal of inertia to policy (also frequently referred to as "interest rate smoothing"). The actual setting of the funds rate must satisfy the ZLB:

$$
i_{t}=\max \left\{0, i_{t}^{u}\right\} .
$$

As shown in Reifschneider and Williams (2000), policy rules like this perform very well in the presence of the ZLB because they promise to keep interest rates low in the future and to allow inflation to rise above its long-run target following bouts of excessively low inflation. In forwardlooking models like FRB/US, this expectation of high future rates of inflation boosts the current rate of inflation.

This inertial policy rule delivers better macroeconomic performance with a 2 percent inflation target than does the classic Taylor rule unconstrained by the ZLB. The bottom panel of table 4 reports the simulated outcomes from the inertial version of the Taylor-type rule where the parameters of the rule were chosen to yield minimum weighted variances of inflation, the output gap, and the nominal interest rate. Nonetheless, in this worst-case environment there are limits to what this simple rule can accomplish, and performance suffers noticeably as the inflation goal is lowered much below 2 percent. I obtain very similar results for a policy rule that targets the price level growing at a deterministic trend rather than the inflation rate. (Eggertsson and Woodford 2003 find that such a rule performs well in the presence of the ZLB.) Price-level targeting rules are closely related to the inertial rules described above but imply a stronger mechanism to raise inflation above the long-run target rate following an episode of below-target inflation. Based on this evidence, there is little gain from switching from an optimized inertial policy to an explicit price-level targeting regime, even with very low steady-state inflation rates. 
A potential problem with these alternative policy approaches is that the public may be confused by monetary policy intentions in the vicinity of the ZLB. For example, the asymmetric policy rule I have described represents a significant deviation from the standard reaction function, which could have unintended and undesirable consequences (Taylor 2007). More generally, all of these alternative policies rely heavily on expectations of future policy actions to influence economic outcomes. As shown by Reifschneider and John Roberts (2006) and by Williams (2006), if agents do not have rational expectations, episodes of a binding ZLB may distort expectations, reducing the benefits of policies that work very well under rational expectations. In particular, inertial and price-level targeting policies cause inflation to rise above the long-run target following an episode where the ZLB constrains policy. Such a period of high inflation could conceivably undermine the public's confidence in the central bank's commitment to price stability and lead to an untethering of inflation expectations. Indeed, central banks are averse to declaring any desire to see a sustained rise in inflation above the target level (Kohn 2009; Walsh 2009).

One method to minimize public confusion is for the central bank to clearly communicate its expectations, including the anticipated policy path, as discussed by Woodford (2005) and by Rudebusch and Williams (2008). ${ }^{15}$ Another approach is to back up that communication with interventions in foreign exchange markets, as proposed by Bennett McCallum (2000), Svensson (2001), and Günter Coenen and Volker Wieland (2003), or by targeting the short to the middle end of the yield curve of Treasury securities, a strategy analyzed by Bruce McGough, Rudebusch, and Williams (2005).

An additional potential problem with highly inertial and price-level targeting policies is that, historically, the price level and interest rates tend to be relatively high as the economy enters a recession, because inflation tends to be high near the end of an expansion. ${ }^{16}$ In these circumstances, such policies imply delayed policy responses early in a downturn. The current episode illustrates this dilemma. As shown in figure 3, inflation had been consistently running above 2 percent in several countries well into 2008. Although model simulations do not bear out these concerns, perhaps there

15. Although a few central banks publish interest rate paths, and the Bank of Canada recently made clear statements about its intended path, most central banks remain unwilling to provide such clear communication of their future policy intentions.

16. This observation is related to the strong correlation between the slope of the yield curve and recessions (Rudebusch and Williams 2009). Past recessions are preceded by periods of monetary tightening in response to periods of high inflation. 
is something missing from the dynamics in the models or the assumed monetary policies.

\section{III.B. Countercyclical Fiscal Policy}

The active use of countercyclical fiscal policy has been excluded from consideration in most quantitative research on the ZLB, including the simulations reported above. The experience of the past decade suggests that this assumption is too stringent and may overstate the future effects of the ZLB by ignoring the ways in which fiscal policy can substitute for monetary policy. The past decade has seen the active use of discretionary countercyclical fiscal policy in many countries. For example, Japan aggressively used fiscal policy to stimulate the economy during the 1990s and in the current recession. The International Monetary Fund (2009) expects discretionary fiscal stimulus to average 1 percent of GDP in the G-20 economies over 2008-10, above and beyond automatic stabilizers and measures to support the financial sector.

Economic theory is clear that in the presence of nominal rigidities, government spending can be useful at reducing the macroeconomic costs associated with the ZLB (see, for example, Eggertsson 2009; Christiano, Eichenbaum, and Rebelo 2009; and Erceg and Lindé 2009). Consider the case where, following a negative shock to the economy, the short-term interest rate declines but cannot fall enough to offset the shock. As a result, the real interest rate rises, consumption falls, and inflation falls. These consequences reduce household welfare. A temporary increase in government purchases will increase output and raise wages and thereby marginal cost, which in turn boosts both current and expected inflation. Given a fixed short-term nominal interest rate constrained by the ZLB, the rise in expected inflation lowers the real interest rate, causing consumption to rise. As a result, the increase in government spending reduces the fluctuations in inflation and the output gap and raises welfare. ${ }^{17}$

In principle, any number of policies aimed at strengthening automatic stabilizers or countercyclical fiscal policy more generally could help mitigate the problems caused by the ZLB. Reifschneider and Roberts (2006), using simulations of the FRB/US model, provide an example of the effects

17. In contrast to the case of government spending, the effects of changes in income taxes when the ZLB is binding can be counterintuitive. In models without credit and liquidity constraints, lowering income taxes can be counterproductive because it lowers marginal costs and thus inflation (Eggertsson and Woodford 2006). In such a model, raising taxes during a downturn can improve welfare. In models with liquidity-constrained consumers, a tax cut can also raise demand. 
of fiscal policy stimulus when the ZLB is constraining policy. Here I consider one simple experiment based on a systematic fiscal policy rule for federal government purchases excluding employee compensation and investment purchases. The estimated fiscal reaction function for this category of purchases (which make up about half of total purchases) in the FRB/US model is given by

$$
\begin{aligned}
g_{t}= & 0.55 g_{t-1}+0.07 g_{t-2}+0.19 g_{t-3}-0.0004 y_{t} \\
& +0.0027 y_{t-1}+\gamma\left(i_{t-1}-i_{t-1}^{u}\right)+\varepsilon_{t},
\end{aligned}
$$

where $g$ is the logarithm of federal purchases in this category, $y_{t}$ is the output gap, and $i^{u}$ is the federal funds rate that would occur absent the ZLB. In the baseline model, $\gamma=0$. I consider the effects of a sustained increase in federal purchases when the ZLB constrains monetary policy by setting $\gamma=0.02$. This value implies that a 1 -percentage-point interest rate gap owing to the ZLB causes total federal purchases to rise by 1 percent in the next period. Lags in fiscal policy implementation are approximated by the lag structure of this equation.

This modified fiscal reaction function cuts the macroeconomic effects of the ZLB in half for low steady-state interest rates of 3 and 4 percent. The bottom panel of table 5 shows the outcomes from this experiment for the Taylor-type rule with $\varphi=1$. The top panel shows the outcome of the same rule without the fiscal response. In the worst-case scenario, an inflation target of 3 percent is sufficient to avoid effects from the ZLB. An inflation target of 2 percent suffers a small increase in output variability. This specification for the fiscal reaction function is in no way meant to be optimal or even desirable, but rather is intended only to illustrate the effects of countercyclical fiscal policy aimed at mitigating the effects of the ZLB on the economy. Further research is needed in this area to devise better countercyclical fiscal policy rules.

\section{III.C. Unconventional Monetary Policy Actions}

The preceding discussion and analysis abstracted from unconventional monetary actions, implicitly assuming that these are not used or are ineffective. However, the events of the past year provide ample evidence that central banks possess and are willing to use tools other than the overnight interest rate. James Clouse and others (2003) and Ben Bernanke and Vincent Reinhart (2004) describe alternative policy tools available to the Federal Reserve. In the current crisis, a number of such alternatives have been put 
Table 5. Simulated Outcomes of Alternative Fiscal Policies ${ }^{\mathrm{a}}$

\begin{tabular}{|c|c|c|c|c|c|c|c|}
\hline \multirow{2}{*}{$\begin{array}{l}\text { Annual } \\
\text { inflation } \\
\text { target } \pi *^{*} \\
{\text { (percent })^{\mathrm{b}}}^{\mathrm{b}}\end{array}$} & \multicolumn{2}{|c|}{$\begin{array}{l}\text { Percent of the time the } \\
\text { federal funds rate } i \\
\text { will be below the } \\
\text { indicated value }\end{array}$} & \multirow{2}{*}{$\begin{array}{l}\text { Percent of } \\
\text { the time } \\
\text { the output } \\
\text { gap will be } \\
\text { below }-4 \%\end{array}$} & \multicolumn{3}{|c|}{$\begin{array}{l}\text { Standard deviations } \\
\text { of the output gap } y \text {, } \\
\text { inflation } \pi \text {, and the } \\
\text { federal funds rate } i\end{array}$} & \multirow[b]{2}{*}{ Loss $L^{\mathrm{c}}$} \\
\hline & $i=0.1 \%$ & $i=1.0 \%$ & & $y$ & $\pi$ & $i$ & \\
\hline \multicolumn{8}{|c|}{ Government does not increase spending when ZLB is reached } \\
\hline 2 & 34 & 41 & 17 & 4.6 & 2.1 & 2.6 & 27.3 \\
\hline 3 & 16 & 22 & 8 & 3.1 & 1.7 & 3.3 & 15.2 \\
\hline 4 & 11 & 15 & 6 & 2.7 & 1.6 & 3.4 & 13.1 \\
\hline 5 & 8 & 12 & 6 & 2.6 & 1.6 & 3.4 & 12.4 \\
\hline 6 & 6 & 10 & 6 & 2.5 & 1.6 & 3.5 & 12.0 \\
\hline 8 & 2 & 3 & 5 & 2.5 & 1.6 & 3.6 & 12.0 \\
\hline 10 & 0 & 1 & 5 & 2.5 & 1.6 & 3.6 & 12.0 \\
\hline \multicolumn{8}{|c|}{ Government increases spending when ZLB is reached } \\
\hline 2 & 31 & 39 & 12 & 3.9 & 2.0 & 2.8 & 21.2 \\
\hline 3 & 16 & 23 & 7 & 2.8 & 1.6 & 3.2 & 13.3 \\
\hline 4 & 12 & 17 & 6 & 2.6 & 1.6 & 3.3 & 12.2 \\
\hline 5 & 8 & 12 & 6 & 2.5 & 1.6 & 3.4 & 11.8 \\
\hline 6 & 6 & 10 & 6 & 2.5 & 1.6 & 3.5 & 11.9 \\
\hline 8 & 2 & 3 & 5 & 2.5 & 1.6 & 3.6 & 12.0 \\
\hline 10 & 0 & 1 & 5 & 2.5 & 1.6 & 3.6 & 12.0 \\
\hline
\end{tabular}

Source: Author's calculations.

a. All simulations use shock covariance data for 1968-83 and assume a steady-state real interest rate $r *$ equal to 1 .

b. The monetary policy rule is assumed to be $i_{t}=\max \left\{0, r_{t}^{*}+\bar{\pi}_{t}+0.5\left(\bar{\pi}_{t}-\pi^{*}\right)+y_{t}\right\}$.

c. $L=\mathrm{E}\left\{\left(\pi-\pi^{*}\right)^{2}+y^{2}+0.25 *\left(i-i^{*}\right)^{2}\right\}$, where $i^{*}=\pi^{*}+r^{*}$.

to use. Several central banks, including the Bank of England, the European Central Bank, the Federal Reserve, and the Bank of Japan, have instituted programs to buy or guarantee assets such as commercial paper and mortgagebacked securities. Finally, the Bank of Japan, the Bank of England, and the Federal Reserve have expanded their holdings of longer-term securities through the creation of reserves. Many of these programs are aimed at improving the functioning of impaired or distressed markets. Similarly, the Federal Reserve's purchases of the debt of government-sponsored enterprises such as Fannie Mae and Freddie Mac, and of mortgage-backed securities, were aimed at particular sectors-housing and finance-that appeared to be functioning poorly. Future recessions may not be accompanied by severe financial market disruptions, in which case these tools would not be as useful at offsetting the shock.

An open question is whether policies that expand the central bank's balance sheet, such as quantitative easing or purchases of longer-term 
government securities, are effective at stimulating the economy. Bernanke, Reinhart, and Brian Sack (2004) provide evidence that shocks to the supply of government securities do affect their prices and yields. Announcements by the Bank of England and the Federal Reserve regarding plans to buy longer-term government securities were followed by large movements in yields, providing additional support that such policy actions can be effective (see Meier 2009 for a summary of the U.K. experience). Nonetheless, a great deal of uncertainty surrounds the magnitude and duration of these effects. In addition, some observers fear adverse consequences from such actions if taken on a large scale, including the risk of large losses and the concern that inflation expectations may become unmoored. Further careful study is needed before these policy options can be counted on as effective substitutes for more traditional monetary policy actions.

\section{Conclusion}

The zero lower bound has significantly constrained the ability of many central banks to stimulate the economy in the current recession. Counterfactual simulations suggest that the ZLB will impose significant output costs on the U.S. economy. Although these simulations focus on the effects of lower U.S. interest rates on the U.S. economy, comparable simulations for other economies where the ZLB has constrained monetary policy—such as Japan and Europe-would no doubt also show that the ZLB has entailed significant costs during the recent episode. A useful extension of the simulations reported in this paper would be to calculate the costs of the ZLB in a model of the global economy.

If the recent episode represents a unique, extraordinary incident, it has no particular implications for future monetary policy with respect to the ZLB. In particular, a 2 percent inflation target should provide an adequate buffer for monetary policy in the future. If, however, the era of the Great Moderation is over but the steady-state real interest rate remains very low, the ZLB may regularly interfere with the ability of central banks to achieve macroeconomic stabilization goals. The analysis in this paper argues that an inflation target of 2 percent may be insufficient to keep the ZLB from imposing sizable costs in terms of macroeconomic stabilization in a much more adverse macroeconomic climate if monetary policy follows the standard Taylor rule.

Given these results, it is important to study and develop monetary and fiscal policies that effectively counter the effects of the ZLB, should the future macroeconomic environment prove adverse. Arguably, the applica- 
tion of some of these approaches over the past two years has helped combat the massive shocks that have buffeted the global economy. Improving these policies and developing new ones into systematic, predictable responses to economic conditions will help make them more effective in the future. In addition, an important lesson from the recent crisis, not addressed in this paper, is the critical need for effective regulation and supervision of financial markets to avoid the shocks to the global economy that ignited the crisis and led to recession.

Finally, this paper has examined only the costs associated with the ZLB, abstracting from the many other sources of distortions related to steady-state inflation. Unfortunately, relatively little research has weighed the costs of the ZLB against these other influences in a coherent, empirically supported framework (see Billi and Kahn 2008 for a review) ${ }^{18}$ More research on these issues is needed.

ACKNOWLEDGMENTS This paper benefited greatly from comments by Richard Dennis, Benjamin Friedman, Michael Woodford, and by the editors and other participants at the Brookings Papers conference. I thank Justin Weidner for excellent research assistance. The opinions expressed are those of the author and do not necessarily reflect the views of the Federal Reserve Bank of San Francisco, the Board of Governors of the Federal Reserve System, or anyone else in the Federal Reserve System.

18. Much of the literature focuses on the welfare costs related to holding zero-interestbearing assets; both Feldstein (1997) and Attanasio, Guiso, and Jappelli (2002) convincingly show that these are trivial. These costs are even lower now that the Federal Reserve and many other central banks pay interest on reserves. 


\section{References}

Adam, Klaus, and Roberto M. Billi. 2006. "Optimal Monetary Policy under Commitment with a Zero Bound on Nominal Interest Rates." Journal of Money, Credit and Banking 38, no. 7: 1877-1905.

Akerlof, George A., William T. Dickens, and George L. Perry. 1996. "The Macroeconomics of Low Inflation.” BPEA, no. 1: 1-59.

Attanasio, Orazio P., Luigi Guiso, and Tullio Jappelli. 2002. "The Demand for Money, Financial Innovation, and the Welfare Cost of Inflation: An Analysis with Household Data." Journal of Political Economy 110, no. 2 (April): 317-51.

Bailey, Martin J. 1956. "The Welfare Cost of Inflationary Finance." Journal of Political Economy 64, no. 2 (April): 93-110.

Benhabib, Jess, Stephanie Schmitt-Grohé, and Martín Uribe. 2001. "The Perils of Taylor Rules." Journal of Economic Theory 96, no. 1-2 (January): 40-69.

Bernanke, Ben S., and Vincent R. Reinhart. 2004. "Conducting Monetary Policy at Very Low Short-Term Interest Rates." American Economic Review 94, no. 2 (May): 85-90.

Bernanke, Ben S., Vincent R. Reinhart, and Brian P. Sack. 2004. "Monetary Policy Alternatives at the Zero Bound: An Empirical Assessment." BPEA, no. 2: 1-78.

Billi, Roberto M., and George A. Kahn. 2008. "What Is the Optimal Inflation Rate?" Federal Reserve Bank of Kansas City Economic Review (Second Quarter): $5-28$.

Bodenstein, Martin, Christopher J. Erceg, and Luca Guerrieri. 2009. "The Effects of Foreign Shocks When U.S. Interest Rates Are at Zero." International Finance Discussion Papers 983. Washington: Board of Governors of the Federal Reserve System (October).

Brayton, Flint, Eileen Mauskopf, David Reifschneider, Peter Tinsley, and John Williams. 1997. "The Role of Expectations in the FRB/US Macroeconomic Model." Federal Reserve Bulletin (April): 227-45.

Carlson, John B., Ben R. Craig, and William R. Melick. 2005. "Recovering Market Expectations of FOMC Rate Changes with Options on Federal Funds Futures." Journal of Futures Markets 25, no. 12 (December): 1203-42.

Christiano, Lawrence, Martin Eichenbaum, and Sergio Rebelo. 2009. "When Is the Government Spending Multiplier Large?" Cambridge, Mass.: National Bureau of Economic Research (October).

Clouse, James, Dale Henderson, Athanasios Orphanides, David H. Small, and P. A. Tinsley. 2003. "Monetary Policy When the Nominal Short-Term Interest Rate Is Zero." Topics in Macroeconomics 3, no. 1, article 12.

Coenen, Günter. 2003. "Zero Lower Bound: Is It a Problem in the Euro Area?" In Background Studies for the ECB's Evaluation of Its Monetary Policy Strategy, edited by Otmar Issing. Frankfurt: European Central Bank.

Coenen, Günter, Athanasios Orphanides, and Volker Wieland. 2004. "Price Stability and Monetary Policy Effectiveness When Nominal Interest Rates Are Bounded at Zero." Advances in Macroeconomics 4, no. 1. 
Coenen, Günter, and Volker Wieland. 2003. "The Zero-Interest-Rate Bound and the Role of the Exchange Rate for Monetary Policy in Japan.” Journal of Monetary Economics 50, no. 5 (July): 1071-1101.

Eggertsson, Gauti B. 2009. "What Fiscal Policy Is Effective at Zero Interest Rates?" Federal Reserve Bank of New York (August).

Eggertsson, Gauti B., and Michael Woodford. 2003. "The Zero Bound on Interest Rates and Optimal Monetary Policy.” BPEA, no. 1: 139-211.

_ 2006. "Optimal Monetary and Fiscal Policy in a Liquidity Trap." In NBER International Seminar on Macroeconomics 2004, edited by Richard H. Clarida, Jeffrey A. Frankel, Francesco Giavazzi, and Kenneth D. West. MIT Press.

Erceg, Christopher J., and Jesper Lindé. 2009. "Is There a Fiscal Free Lunch in a Liquidity Trap?" Washington: Board of Governors of the Federal Reserve System (April).

Evans, George W., Eran Guse, and Seppo Honkapohja. 2008. "Liquidity Traps, Learning and Stagnation.” European Economic Review 52, no. 8: 1438-63.

Federal Open Market Committee. 2002. "FOMC Briefing." Washington: Board of Governors of the Federal Reserve System (January).

Federal Reserve Bank of Philadelphia. 2009. "Survey of Professional Forecasters, Third Quarter 2009" (August 14).

Feldstein, Martin. 1997. "The Costs and Benefits of Going from Low Inflation to Price Stability." In Reducing Inflation: Motivation and Strategy, edited by Christina D. Romer and David H. Romer. University of Chicago Press.

Glick, Reuven, and Kevin J. Lansing. 2009. "U.S. Household Deleveraging and Future Consumption Growth." FRBSF Economic Letter 2009-16. Federal Reserve Bank of San Francisco (May 15).

International Monetary Fund. 2009. "The State of Public Finances: Outlook and Medium-Term Policies after the 2008 Crisis." Washington (March 6).

Kohn, Donald L. 2009. "Monetary Policy Research and the Financial Crisis: Strengths and Shortcomings." Presented at the Federal Reserve Conference on Key Developments in Monetary Policy, Washington, October 9.

Kuttner, Kenneth N. 2004. "A Snapshot of Inflation Targeting in Its Adolescence." In The Future of Inflation Targeting, edited by Christopher Kent and Simon Guttmann. Sydney: Reserve Bank of Australia (November).

Laubach, Thomas. 2009. "New Evidence on the Interest Rate Effects of Budget Deficits and Debt." Journal of the European Economic Association 7, no. 4 (June): 858-85.

Laubach, Thomas, and John C. Williams. 2003. "Measuring the Natural Rate of Interest." Review of Economics and Statistics 85, no. 4 (November): 1063-70.

Levin, Andrew T., and John C. Williams. 2003. "Robust Monetary Policy with Competing Reference Models.” Journal of Monetary Economics 50, no. 5 (July): 945-75.

McCallum, Bennett T. 2000. "Theoretical Analysis Regarding a Zero Lower Bound on Nominal Interest Rates." Journal of Money, Credit and Banking 32, no. 4 (November): 870-904. 
McGough, Bruce, Glenn D. Rudebusch, and John C. Williams. 2005. "Using a Long-Term Interest Rate as the Monetary Policy Instrument." Journal of Monetary Economics 52, no. 5 (July): 855-79.

Meier, André. 2009. "Panacea, Curse, or Nonevent? Unconventional Monetary Policy in the United Kingdom.” IMF Working Paper 09/163 (August). Washington: International Monetary Fund.

Orphanides, Athanasios, and John C. Williams. 2002. "Robust Monetary Policy Rules with Unknown Natural Rates.” BPEA, no. 2: 63-118.

—. 2007. "Robust Monetary Policy with Imperfect Knowledge." Journal of Monetary Economics 54, no. 5 (July): 1406-35.

Orphanides, Athanasios, Richard D. Porter, David Reifschneider, Robert Tetlow, and Frederico Finan. 2000. "Errors in the Measurement of the Output Gap and the Design of Monetary Policy." Journal of Economics and Business 52, no. 1-2: $117-41$.

Reifschneider, David L., and John M. Roberts. 2006. "Expectations Formation and the Effectiveness of Strategies for Limiting the Consequences of the Zero Bound." Journal of the Japanese and International Economies 20, no. 3 (September): 314-37.

Reifschneider, David L., and John C. Williams. 2000. "Three Lessons for Monetary Policy in a Low-Inflation Era." Journal of Money, Credit, and Banking 32, no. 4, part 2 (November): 936-66.

Romer, Christina D., and David H. Romer. 2002. "A Rehabilitation of Monetary Policy in the 1950's." American Economic Review 92, no. 2 (May): 121-27.

Rudebusch, Glenn D. 2009. "The Fed's Monetary Policy Response to the Current Crisis." Federal Reserve Bank of San Francisco Economic Letter 2009-17 (May 22).

Rudebusch, Glenn D., and John C. Williams. 2008. "Revealing the Secrets of the Temple: The Value of Publishing Central Bank Interest Rate Projections." In Asset Prices and Monetary Policy, edited by John Y. Campbell. University of Chicago Press.

- 2009. "Forecasting Recessions: The Puzzle of the Enduring Power of the Yield Curve." Journal of Business and Economic Statistics 27, no. 4 (October): 492-503.

Svensson, Lars E. O. 2001. "The Zero Bound in an Open Economy: A Foolproof Way of Escaping from a Liquidity Trap." Monetary and Economic Studies 19, no. S-1 (February): 277-312.

Svensson, Lars E. O., and Robert Tetlow. 2005. "Optimum Policy Projections." International Journal of Central Banking 1, no. 3 (December): 177-207.

Taylor, John B. 1993. "Discretion versus Policy Rules in Practice." CarnegieRochester Conference Series on Public Policy 39: 195-214.

. 2007. "Housing and Monetary Policy." In Housing, Housing Finance, and Monetary Policy: A Symposium Sponsored by the Federal Reserve Bank of Kansas City. Kansas City, Mo. 
Walsh, Carl E. 2009. "Using Monetary Policy to Stabilize Economic Activity." Paper presented at the Federal Reserve Bank of Kansas City Symposium on Financial Stability and Macroeconomic Policy, Jackson Hole, Wyo.

Weidner, Justin, and John C. Williams. 2009. "How Big Is the Output Gap?" Federal Reserve Bank of San Francisco Economic Letter 2009-19 (June 12; updated September 9, 2009).

Williams, John C. 2006. "Monetary Policy in a Low Inflation Economy with Learning." In Monetary Policy in an Environment of Low Inflation: Proceedings of the Bank of Korea International Conference 2006. Seoul: Bank of Korea.

2009. "The Risk of Deflation." Federal Reserve Bank of San Francisco Economic Letter 2009-12 (March 27).

Woodford, Michael. 2003. Interest and Prices: Foundations of a Theory of Monetary Policy. Princeton University Press.

2005. "Central-bank Communication and Policy Effectiveness." In The Greenspan Era: Lessons for the Future: A Symposium Sponsored by the Federal Reserve Bank of Kansas City. Kansas City, Mo. 


\section{Comment and Discussion}

\section{COMMENT BY}

MICHAEL WOODFORD This paper by John Williams reassesses the significance for the choice of an inflation target of a consideration stressed by Lawrence Summers (1991), namely, that too low a target will interfere with the success of monetary stabilization policy, because policy will too frequently be constrained by the zero lower bound on nominal interest rates. This argument began to be taken more seriously by both central bankers and monetary economists after Japan reached the zero bound in the late 1990s, and I think the consensus view regarding the desirable level for an inflation target shifted at least slightly higher after that experience. Many countries had lowered their inflation rates (often in a series of steps) over the course of the 1980s and 1990s, but it was not clear whether this process of disinflation should be regarded as having been completed, or at what point it would be appropriate to stop. Before the Japanese experience showed that the zero bound could indeed be a binding constraint, an important current of opinion argued for the desirability of zero inflation (full "price stability") or even mild deflation (to reduce the opportunity cost of holding money to zero, as called for by Friedman 1969). After observing the Bank of Japan's inability to pull the Japanese economy out of its continuing deflationary slump over a period of years, many economists came to accept that inflation targets on the order of 2 percent a year-a level already commonplace among the industrial nations with explicit targets-were quite possibly low enough.

Williams asks, however, whether recent events-in which the Federal Reserve and a great many other central banks found themselves at the effective lower bound to which they were willing to reduce their policy rates, amid a global recession - might not justify a further upward revision in inflation targets. The question Williams poses is not whether the zero 
lower bound is a reason to forgo the benefits of deflation at the rate called for by Friedman, or even the benefits of full price stability, but whether even a 2 percent inflation target does not make the zero lower bound too great a constraint on effective stabilization policy. After all, central banks like the Federal Reserve have found themselves constrained by the zero bound during the current crisis, despite explicit or implicit inflation targets on the order of 2 percent. The general tenor of the paper's conclusions is that it might indeed be prudent to aim for a moderately higher rate of inflation, perhaps as high as 4 percent a year, which, in the context of U.S. policy, would mean aiming for a rate clearly higher than that pursued for the past two decades.

This conclusion contrasts with that reached by Williams himself in his analyses of the issue only a few years ago (for example, Reifschneider and Williams 2000; Williams 2006), which represent, in my view, some of the best work available on this topic. What accounts for the difference? Williams proposes two reasons in particular for greater caution now about the suitability of a low inflation target. One is that past studies may have assumed too low a frequency of large shocks. This is a crucial issue, since the zero bound is a constraint on interest rate policy only to the extent that one would sometimes like to be able to cut real interest rates substantially, and how often that situation arises depends on the size of certain kinds of real disturbances to the economy. Williams proposes that studies that parameterize shock processes based on data from the "Great Moderation" period of the mid- to late 1980s and the 1990s may underestimate the frequency of large shocks, on the grounds that this period may have been atypically calm; as a robustness check, he instead conducts stochastic simulation exercises using a shock distribution estimated on the basis of data from the period 1968-83 only, so as to exclude the arguably atypical years that followed.

The other reason for caution is that past studies may have assumed too high a value for the average equilibrium real rate of interest. This is also a crucial issue, since the average level of nominal interest rates associated with a given inflation target-and hence the number of percentage points by which interest rates can be cut, if necessary, before hitting the zero lower bound-is greater, the higher the average equilibrium real rate of interest. Williams cites estimates suggesting that the equilibrium real rate of interest in the United States has fallen in recent years, from a range of 2.5 to 3 percent a year in the 1980 s to only about 1 percent at present. If this represents a permanent structural change, he suggests, it may be appropriate to simulate the consequences of alternative policy rules assuming an 
average equilibrium real rate as low as 1 percent. Both of these proposed changes in the numerical assumptions used in his stochastic simulations increase the degree to which the zero bound is predicted to interfere with economic stabilization, under a Taylor rule with an implicit inflation target of 2 percent a year.

Although I am sympathetic with the view that it is important to undertake sensitivity analysis of quantitative conclusions to alternative assumptions, especially with regard to the values of parameters about which one cannot claim that the historical record provides conclusive evidence, it is difficult to be sure how much weight to place on the results obtained under Williams's "worst-case" scenarios (those that use shocks from the period 1968-83 and assume an equilibrium real rate of only 1 percent). One could also argue, with some plausibility, that $1968-83$ was a period of atypically high macroeconomic instability. (Some of that instability may have been due to policy mistakes, rather than to genuinely exogenous disturbances to economic fundamentals, but it may show up as larger residuals in the equations of the structural model used in Williams's exercise, owing to misspecification of some of the model equations. In that case, residuals of this size should not be expected to be a recurrent feature of economic dynamics under a stable policy rule that provides a stronger nominal anchor.) It is even less clear that it makes sense to assume that the equilibrium real rate of interest will continue to be 1 percent a year. If the equilibrium real rate has fallen by an entire percentage point (or more) leading up to and during the current financial crisis (as indicated by the Laubach-Williams estimates shown in Williams's figure 8), this is surely due to temporary disruption of the financial system, rather than some kind of permanent structural change that happens to coincide precisely in time with the crisis. Hence, it is plausible to assume that the equilibrium real rate should again be 2 percent or higher, once the recent problems in the financial sector have largely been overcome. Other factors that have contributed to a somewhat lower equilibrium real rate of return over the past decade, such as the remarkable accumulation of dollar assets by Asian central banks, may well prove temporary as well, leading to an equilibrium real rate of return more like that observed in past decades.

Even under his worst-case assumptions, Williams's results provide modest support at best for an inflation target higher than 2 percent. The main results that he emphasizes concern the stability of output and inflation under a "simple" Taylor rule with one implicit inflation target or another; Williams argues that the greater stability of real activity under an inflation target of 3 or even 4 percent is sufficient to offset the harm done by the 
higher average rate of inflation under such rules. But as his paper shows, more sophisticated monetary policy rules could achieve better outcomes, even with an average inflation rate of 2 percent (or less).

In fact, as stressed by previous papers such as Reifschneider and Williams (2000) and Eggertsson and Woodford (2003), a "simple" Taylor rule is a relatively poor form of policy rule in the case that the zero bound sometimes binds, because it is a commitment to a purely forward-looking policy. This means that once the zero bound ceases to bind, monetary policy is immediately conducted in the same way as it would be if the bound had not constrained policy. Hence, the central bank's opportunity to commit itself to a systematic approach to policy is not used to create expectations about how policy will be conducted after an episode in which the zero bound is reached that respond in any way to that situation. In fact, the advantage of a higher inflation target in the simulations in this paper derives entirely from the consequences of having people expect a higher inflation target immediately following the exit from a period in which the zero bound has been a binding constraint; the expectation of a higher inflation rate at that time lowers the expected real rate implied by the zero nominal interest rate floor, and this reduces the distortions caused by the existence of that floor. But to achieve this benefit, it is (at least in principle) not necessary to have a higher inflation target all of the time; it suffices to follow a policy that allows higher inflation for a very brief period following any period in which the zero bound causes one to undershoot one's normal target; the inflation target can still be 2 percent (or even lower) at all other times.

The "history-dependent" policy rules proposed in Reifschneider and Williams (2000) and in Eggertsson and Woodford (2003) serve exactly this purpose. As long as the fraction of the time in which the zero bound is a binding constraint is not too large, such rules achieve a substantially higher level of welfare than any purely forward-looking (or constant-inflationtarget) policy, as shown by Eggertsson and Woodford (2003), and the optimal rule involves an average inflation rate that is only slightly higher than would be optimal if the zero bound were never a constraint. Indeed, it is not obvious that any increase in the average inflation rate is necessary in order to deal with the zero lower bound in a reasonably effective way. Eggertsson and Woodford show, in an admittedly simple model, that a good approximation to optimal policy can be achieved - and the distortions resulting from the zero bound under a constant inflation target largely avoided - by a simple price-level targeting rule that implies a zero rate of inflation over the long run. Under this rule the only commitment to inflation is a commitment to make up for any decline in the price level that occurs 
during the period in which the zero bound prevents the target from being hit; this brings about inflation expectations of the size necessary to prevent the zero bound from creating significant distortions (for if there were more substantial distortions, the sharper decline in prices would automatically create correspondingly higher expectations of inflation as soon as inflation can be achieved with a nonnegative interest rate).

An important question about this solution to the problem of the zero bound is whether it is likely that such a commitment to subsequent reflation can actually be made credible to the public, so that inflation expectations are affected in the desired way. (Walsh 2009 discusses the skepticism of many central bankers about such proposals.) One might argue that restricting attention to simple Taylor rules with alternative constant inflation targets is sensible, on the grounds that more complex rules would not be understood or believed in. But the kind of commitment that would solve the problem is not too difficult to explain; as just noted, it would simply require commitment to a price-level target or, more realistically, to a target path for the price level (or for some other nominal variable, such as nominal GDP). Moreover, even if one supposes that private sector inflation expectations cannot be shifted by mere announcements about future policy intentions, it would be desirable to explicitly analyze the kind of policy that would best shape those expectations in a way that mitigates the distortions caused by the zero bound. Williams (2006) addresses this question in the context of an explicit model of "learning" dynamics and finds that some rules that would be effective at stabilizing the economy despite the zero bound under an assumption of rational expectations are less desirable under learning dynamics. Nonetheless, he finds that "a robust strategy to cope with both imperfect knowledge and the zero bound is to respond more strongly to inflation" when not at the zero bound "than would be optimal under rational expectations." Even with learning dynamics, such a rule is found to be "effective at stabilizing inflation and output ... even with a low inflation target" (Williams 2006, abstract).

Another possible response to a perceived inability to make a credible commitment to history-dependent policy is to use fiscal policy to prevent a severe contraction and deflation once the zero bound is reached. Under the assumption that the central bank follows a simple Taylor rule except when the zero bound is reached, New Keynesian models often imply quite large output multipliers for increases in government purchases while monetary policy continues to be constrained by the zero bound (Eggertsson 2009; Christiano, Eichenbaum, and Rebelo 2009). Of course, such a policy response is not under the control of the central bank. Nonetheless, reliance 
on fiscal policy to mitigate the problems that could otherwise be created by the zero bound has two advantages: first, that the deviation from policy as usual is one that can already be observed at the time that one wishes for the policy to be credible (that is, when the zero bound constrains monetary policy), and second, that the effectiveness of the policy does not depend on any change in expectations about how policy will be conducted after the unusual circumstances cease to obtain. (In fact, the analyses just cited imply that the output effect of government purchases is greatest when the public does not expect that the increased government purchases will continue after the zero bound no longer constrains monetary policy.) Relative to a policy of creating higher inflation expectations while at the zero bound by aiming at a higher inflation target all of the time, the alternative of activist fiscal policy during crises has the advantage of not increasing economic distortions at other times. This is a substantial advantage if the economy is not at the zero bound too much of the time.

Finally, even supposing that the relevant choice is among alternative inflation targets under a simple Taylor rule, with no assistance from fiscal policy, and even accepting Williams's worst-case assumptions under which the policy simulations should be conducted, the quantitative results that Williams announces do not make all that strong a case for an inflation target higher than 2 percent. According to the bottom panel of his table 2 (the case of shocks drawn from the 1968-83 distribution), and under the assumption that the steady-state real interest rate $r^{*}=1$ percent, increasing the inflation target from 2 percent to 4 percent would lower the standard deviation of $\log$ output from 3.3 percent to 3.0 percent, with no measurable effect (to two significant digits) on the standard deviations of inflation or interest rates. But would this degree of improvement in the stability of aggregate output really justify 2 percentage points higher inflation?

The most serious reason to fear that an increase in the Federal Reserve's implicit inflation target to 4 percent could do real harm is the likelihood that such a shift would increase doubts about the extent to which the Federal Reserve is truly committed to any inflation target at all: if, as a result of a recession, the inflation target can be increased from the 1.5 to 2 percent range that many members of the Federal Open Market Committee were thought to prefer in the recent past to a target of 4 percent, what further shifts in the inflation rate might the Federal Reserve find acceptable in response to further unforeseen events? Such considerations are not taken into account in Williams's simulations, which assume perfect constancy and perfect credibility of whichever inflation target is contemplated. But even supposing that the consequences would be those indicated in table 2 , one 
might easily conclude that 2 percentage points higher inflation at all times would increase distortions by more than the improved output stabilization would reduce them.

The "loss measure" reported in table 2 assumes that losses result only from squared deviations of inflation, output, and the nominal interest rate from their steady-state values, even though the steady-state values of inflation and of the nominal interest rate are quite different in the equilibria associated with alternative inflation targets. Thus, the gains reported from moving from the 2 percent inflation target to a 4 percent target take no account at all of any reason why a higher average inflation rate (or a higher average nominal interest rate) would be undesirable. It therefore abstracts entirely from the considerations that are at the center of most discussions of the optimal inflation target (as surveyed, for example, in Schmitt-Grohé and Uribe 2009). One might easily assign values to those other considerations that would outweigh the improvement in output stabilization shown in the table.

As a simple example, the familiar Calvo model of staggered price adjustment implies the existence of losses deriving from the misalignment of prices that are adjusted at different times that are (in a second-order approximation to expected utility, as discussed in Woodford 2003, chapter 6) proportional to $\mathrm{E}\left[\pi_{t}^{2}\right]$ rather than to $\mathrm{E}\left[\left(\pi_{t}-\pi^{*}\right)^{2}\right]$. If one assumes that the losses due to inflation variability are of this sort, then the term $\mathrm{E}\left[\left(\pi_{t}-\pi^{*}\right)^{2}\right]$ in the loss measure (equation 3) should be replaced by

$$
\mathrm{E}\left[\pi_{t}^{2}\right]=\pi^{* 2}+\mathrm{E}\left[\left(\pi_{t}-\pi^{*}\right)^{2}\right] .
$$

When this substitution is made (but otherwise assuming the relative weights on the three stabilization objectives given in equation 3), the loss measure associated with the 2 percent inflation target (in the bottom panel of table 2) increases from 15.5 to 19.5 , while the loss associated with the 4 percent inflation target increases from 13.6 to 29.6. Hence, the increase in the inflation target would result in substantially greater losses rather than the modest improvement that the table suggests. Indeed, under this correction the 1 percent inflation target (the lowest considered in the table) would be the one with the lowest losses. If one were also to take account of the "shoe-leather costs" resulting from unnecessary economizing on cash balances, which should be an increasing function of $i^{*}$, this conclusion would only be strengthened.

Thus, the case that is presented for the desirability of an inflation target higher than 2 percent is quite weak. My own summary of Williams's results 
would be that even under assumptions that are chosen to be as unfavorable as possible to a low inflation target-larger shocks, a very low assumed value for $r^{*}$, restriction of attention to simple Taylor rules, and no help from fiscal policy—stochastic simulations that take into account the zero lower bound on nominal interest rates provide little support for the desirability of an inflation target as high as 2 percent, let alone an even higher target.

\section{REFERENCES FOR THE WOODFORD COMMENT}

Christiano, Lawrence, Martin Eichenbaum, and Sergio Rebelo. 2009. "When Is the Government Spending Multiplier Large?" Working Paper no. 15394. Cambridge, Mass.: National Bureau of Economic Research (October).

Eggertsson, Gauti B. 2009. "What Fiscal Policy Is Effective at Zero Interest Rates?" Staff Report no. 402. Federal Reserve Bank of New York (November).

Eggertsson, Gauti B., and Michael Woodford. 2003. "The Zero Bound on Interest Rates and Optimal Monetary Policy." BPEA, no. 1: 139-211.

Friedman, Milton. 1969. "The Optimum Quantity of Money." In The Optimum Quantity of Money and Other Essays. Chicago: Aldine.

Reifschneider, David, and John C. Williams. 2000. "Three Lessons for Monetary Policy in a Low-Inflation Era." Journal of Money, Credit, and Banking 32 no. 4, part 2: 936-66.

Schmitt-Grohé, Stephanie, and Martín Uribe. 2009. "The Optimal Rate of Inflation." Columbia University (November).

Summers, Lawrence. 1991. "How Should Long-Term Monetary Policy Be Determined?" Journal of Money, Credit, and Banking 23, no. 3, part 2: 625-31.

Walsh, Carl E. 2009. "Using Monetary Policy to Stabilize Economic Activity," presented at the Federal Reserve Bank of Kansas City Symposium on Financial Stability and Macroeconomic Policy, Jackson Hole, Wyo.

Williams, John C. 2006. "Monetary Policy in a Low Inflation Economy with Learning." Working Paper no. 2006-30. Federal Reserve Bank of San Francisco (September).

Woodford, Michael. 2003. Interest and Prices: Foundations of a Theory of Monetary Policy. Princeton University Press.

GENERAL DISCUSSION Robert Hall suggested that the literature on the zero lower bound overlooks the possibility of a negative federal funds rate. A negative funds rate can be achieved by charging banks for holding reserves rather than paying interest on them. Then banks would pay each other to take their unwanted reserves, generating the pressure to lend that achieves the desired stimulus. Hall argued that economists should encourage Congress to permit the Federal Reserve to charge for reserves. 
Christopher Sims observed that the Swedish Riksbank already has a negative-interest-rate policy, which it implements by charging interest on reserves. However, there are limits to how far one can push interest rates into negative territory by this means. Cash pays zero interest, which means that if the interest rate is negative enough, banks will substitute cash in the vault for reserve balances and so avoid the negative interest rate. Benjamin Friedman agreed with Hall that it is just an administrative matter whether the Federal Reserve charges interest on banks' accounting balances of reserves. Moreover, under the right legislation, it would not matter whether the reserves were held in the form of balances at the Federal Reserve or vault cash. Both could be charged. Sims responded that although the Federal Reserve could indeed charge banks interest on vault cash, it cannot charge interest on cash in general. And so long as there exists an asset (cash) that pays nonnegative nominal interest, the effective marginal cost of borrowing cannot be pushed much below zero.

Christopher House noted that the reason that the money supply is not discussed as a policy instrument in modern monetary models with price rigidity is that the money demand side of the model can usually be inverted to express policy in terms of a nominal interest rate. This works as long as the nominal interest rate is above the lower bound. An alternative way of conducting monetary policy in such an event would be to focus less on the federal funds rate, and more on other types of policy instruments. In fact, House pointed out, the Federal Reserve has been doing some of this already through quantitative easing.

Vincent Reinhart underscored House's point by noting that one's degree of concern about the zero lower bound depends on one's assessment of how effective policy is at the lower bound. He also observed that the treatment of the inflation goal in Williams's paper is symmetric, but central bankers often sound very asymmetric in discussing their inflation goals: shortfalls of inflation below the target seem to represent evidence of increased credibility, whereas any excess poses a danger of losing credibility. He wondered what the right inflation goal is if one believes that central bankers will deal with departures from it asymmetrically.

David Laibson noted that the paper did not address the effects of downward nominal wage rigidity on the calculation of the optimal inflation rate. $\mathrm{He}$ wondered to what extent the issue is still as relevant as it was when George Akerlof, William Dickens, and George Perry first brought it to the Panel's attention in their 1996 Brookings Paper, or whether it is now considered to be a second-order issue in light of subsequent research. If the issue is still important, how does it affect the paper's analysis? George Perry responded 
that their research indicated that the issue remained relevant as of not very long ago. They still found an abrupt discontinuity below zero, which made sense given how labor markets are thought to work. But the Akerlof, Dickens, and Perry results had been subject to an important amendment: they are relevant to an economy near full employment, not one in deep recession.

Christopher Sims thought the Federal Reserve ought to talk about at least being willing to tolerate higher inflation than it has previously targeted. He did not see a price-level target, which Michael Woodford had espoused in his comment, as a good idea: although it might be attractive in the current situation because of the zero lower bound, it is not so attractive in a situation following high inflation, perhaps accompanied by a recession, because then the price-level target would indicate a need to deflate. What is needed in that case is to convince the public that the Federal Reserve is willing to tolerate higher future inflation, and that is not the same as a price-level target.

David Romer highlighted for the Panel what he saw as a striking number in the paper: $\$ 1.8$ trillion, which is roughly the cumulated output cost over the next several years of the zero lower bound, or the difference between output as currently projected and what output would be with an additional 400 basis points of stimulus. That is a huge number and raises major policy issues. Romer observed that the academic literature that predated the crisis gave a clear answer about what policy is supposed to do in this situation: it should promise temporarily high inflation. He was therefore puzzled, not by the fact that central bankers have not done that, but by the fact that they never seemed to seriously consider it. He felt that the view due to Kenneth Rogoff, that the world needs conservative central bankers, has perhaps been taken a little too far. Today's central bankers seem allergic to inflation at any level and unwilling even to talk about it under any circumstances.

Alan Blinder reminded the Panel that when one is talking about whether inflation should be 2 or 3 or 4 percent, as opposed to whether it should be zero or 12 percent, another issue becomes relevant, namely, bias in the inflation measure. The science of inflation measurement is not at the state where it can confidently distinguish between zero and 2 percent, or between 2 and 4 percent inflation.

Justin Wolfers felt that the paper's treatment of the natural rate of unemployment might understate the situation. Disinflation can easily start to cause long-term unemployment problems, which can in turn cause the natural rate to creep upward, resulting in large, persistent output shortfalls. If there is even a reasonable probability of such an effect, Wolfers asserted, the magnitudes involved could well swamp just about everything else and boost the figure of $\$ 1.8$ trillion. 
Timothy Besley argued that it is premature to try to assess the welfare implications of the zero lower bound, because so far we have little experience of periods when interest rates are hitting the bound on a regular basis, or of how central banks can and will respond. He recalled from his tenure on the Bank of England Monetary Policy Committee that as Britain approached the zero lower bound, it was clear that there would be a lot of pressure for some sort of action when the lower bound was reached, but very unclear what would be done. Monetary policymakers still have a lot to learn about effective policy at the lower bound, which can only come from experience. Besley also noted that the coordination of fiscal and monetary policy becomes more important when one begins to encounter the zero bound with some regularity, and such coordination could lead to fundamental changes in the nature of the central bank's independence.

Richard Cooper observed that the available quantitative information concerning the lower bound comes overwhelmingly, or even exclusively, from the United States, yet the paper tries to draw lessons that go well beyond the United States. More empirical data from other countries are needed. He supposed that wage rigidity in the United States is less than what it was two decades ago, and he was unsure whether the same would be true of other countries. To the extent that wage rigidity is important, one has to look not only at these macroeconomic phenomena, but also at the allocative implications of an inflation target, because if nominal wages are rigid, one can get much more movement in real wages with a higher inflation target.

Christopher Carroll noted that only two or three years ago, before the dramatic events of recent months, some academic papers had come to the conclusion that hitting the zero lower bound was essentially a zeroprobability event and could be ignored. Now the zero-probability event has happened, and the response seems to be "Oh, when you recalibrate with the new data, it's not a zero-probability event any more, just rare." Carroll wondered whether this reaction is an unhealthy sign that the whole literature has gone seriously astray and has overestimated the state of knowledge on some fundamental questions, by requiring that all answers to those questions be shoehorned into the model through their implications for a couple of model parameters such as the target inflation rate or the cost of quadratic inflation deviations. He proposed a return to some more foundational questions that have not been satisfactorily settled. For example, what are the costs of inflation, and are they captured in the current models? He thought Stanley Fischer may have come close to the truth with his idea that the biggest cost of higher inflation is that it creates more uncertainty, but then inflation becomes simply an intermediary indicator of uncertainty, in which 
case the real issue becomes the effect of monetary policy on uncertainty, not on inflation.

Benjamin Friedman commented that the current behavior of central banks seems to provide dramatic evidence that they are not solely concerned about rising inflation. With the zero lower bound currently binding, one would want to have a more negative real interest rate, and yet it is precisely at this moment that the Federal Reserve seems most eager to demonstrate that it will seek at all costs to withdraw the excess liquidity in a way that will not lead to inflation.

Friedman also wondered whether the paper could make the point more persuasively that hitting the zero lower bound did not make the current recession any deeper. The claim, as he understood it, was that the zero lower bound could not have contributed to the precipitous decline in GDP in the first quarter of 2009, because of the usual lags with which monetary policy affects the economy. But in light of the role that expectations play, more justification is needed to say that there was no difference between, on the one hand, the Federal Reserve cutting the funds rate to zero and telling the public that it was through, and on the other, the Federal Reserve making very clear that it was willing to do whatever was required to prop up the economy.

Ricardo Reis commented that the value of an inflation target is as a means of conveying the central bank's commitment to a given level of inflation, so that agents come to expect that level of inflation in their pricing and output decisions. Just five years ago, when the optimal inflation target was being discussed, there was agreement that it should be between around zero and 2 percent. No one was seriously proposing 4 percent. Now, however, the discussion is whether it should be 2 or 4 or maybe even 5 percent. It seemed to Reis that when the economy gets into serious difficulty, the discussion turns to exit strategies, and higher targets suddenly become acceptable. But he worried that once out of the crisis, those higher rates would again become laughable and the discussion would return to lower rates. There thus seemed to be a disconnect in the current discussion: as long as the target itself is being reassessed every few years, it undermines the commitment that justifies the desire for a target in the first place.

Gita Gopinath reminded the panel of another policy option available to policymakers confronting the zero lower bound, namely, depreciating the currency. This was raised by Ben Bernanke during the Japanese deflation but seldom comes up in other contexts. There are some reasons why this is so, but perhaps depreciation should be discussed as one of the ways of dealing with the lower bound. 
